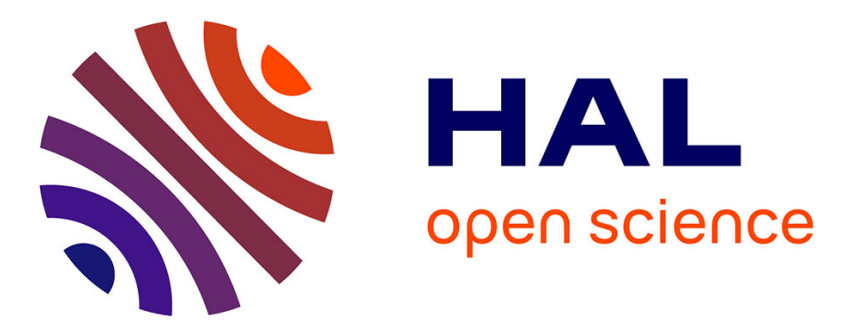

\title{
Understanding plant-arthropod interactions in multitrophic communities to improve conservation biological control: useful traits and metrics
}

\author{
Antoine Gardarin, Manuel Plantegenest, Armin Bischoff, Muriel
}

Valantin-Morison

\section{To cite this version:}

Antoine Gardarin, Manuel Plantegenest, Armin Bischoff, Muriel Valantin-Morison. Understanding plant-arthropod interactions in multitrophic communities to improve conservation biological control: useful traits and metrics. Journal of Pest Science, 2018, 91 (3), pp.943-955. 10.1007/s10340-0180958-0 . hal-01778315

\section{HAL Id: hal-01778315}

\section{https://hal-univ-avignon.archives-ouvertes.fr/hal-01778315}

Submitted on 14 May 2018

HAL is a multi-disciplinary open access archive for the deposit and dissemination of scientific research documents, whether they are published or not. The documents may come from teaching and research institutions in France or abroad, or from public or private research centers.
L'archive ouverte pluridisciplinaire $\mathbf{H A L}$, est destinée au dépôt et à la diffusion de documents scientifiques de niveau recherche, publiés ou non, émanant des établissements d'enseignement et de recherche français ou étrangers, des laboratoires publics ou privés. 


\section{Understanding plant-arthropod interactions in multitrophic}

\section{2 communities to improve conservation biological control:}

\section{3 useful traits and metrics}

4

5

6

7

8

9

10

11

12

13

14

15

16

17

18

Antoine Gardarin ${ }^{1}$, Manuel Plantegenest ${ }^{2}$, Armin Bischoff ${ }^{3}$ and Muriel Valantin-Morison ${ }^{1}$

Corresponding author: Antoine.Gardarin@inra.fr. +33130815440.

${ }^{1}$ UMR Agronomie, INRA, AgroParisTech, Université Paris-Saclay, 78850 Thiverval-Grignon, France

${ }^{2}$ UMR1349 IGEPP, Agrocampus Ouest, 65 rue de Saint-Brieuc, CS 84215, 35042 Rennes Cedex,

France

${ }^{3}$ UMR Mediterranean Institute of Biodiversity and Ecology (IMBE), Aix-Marseille University-CNRSIRD-University of Avignon, IUT Agroparc, 84911 Avignon, France

\section{Acknowledgements}

This work was partly supported by the Agence Nationale de la Recherche PEERLESS project (ANR12-AGRO-0006). We thank the reviewers for their helpful comments on the manuscript. 


\section{Summary}

The role of biodiversity in the delivery of ecosystem services is increasingly being studied by traitbased functional approaches. Here, we review and discuss the contribution of a trait-based approach to understanding plant-arthropod interactions and improving conservation biological control. The stable biological control of multispecies herbivore communities requires functional diversity and a redundancy of natural enemies, including specialists and generalists, with minimal antagonistic interactions. The management of arthropod communities through plant community requires the plant community to perform several functions, including the provision of diversified trophic resources and appropriate physical habitats. Many studies have investigated the ability of plants to provide these functions, but many of the results obtained were limited to single species. The description of communities in terms of traits underlying trophic and non-trophic interactions between plants and animals would make it possible to extrapolate findings to other species. Studies on plant-herbivore and plant-pollinator interactions have identified several traits as important for trophic resource provision, in terms of resource quantity, accessibility, quality and temporal availability. By contrast, traits relating to physical habitat provision and microclimate modification have been little explored. Several metrics describing the functional composition and diversity of communities have been proposed, to extend the trait-based approach to plant community level, but the extent to which multitrophic communities are affected by plant traits remains largely unexplored. The next step will be to identify the combinations of these plant community metrics best explaining their impact on arthropod communities and disentangling the roles of plant functional composition and diversity.

\section{Keywords: entomophagous arthropods; flower strip; functional diversity; functional trait; interaction} trait; natural enemy 


\section{Key message}

51 - The management of arthropod communities for conservation biological control requires plant

52 communities to provide diversified trophic resources and physical habitats.

53 - A trait-based approach would provide more generic knowledge.

54 - Several interaction traits relating to resource provision have been identified, but traits relating to 55 physical habitat provision have been little identified.

56 - At community level, it remains unclear how multitrophic communities are affected by plant traits.

\section{Author contribution statement}




\section{7 Introduction}

There is increasing evidence that semi-natural habitats provide a wide range of services (Wratten et al. 2012) dependent on ecosystem functioning and on its interactions with the management of these habitats. The role of biodiversity in ecosystem service provisioning is increasingly being studied by trait-based functional approaches investigating the relationships between environmental variables, including habitat management, and ecosystem functioning, community assembly and structure. Traitbased approaches are widely used in plant ecology (e.g. Lavorel et al. 2011) and have been extended to studies of other taxonomic groups, such as soil invertebrates (Birkhofer et al. 2017; Pey et al. 2014), but studies connecting different trophic levels on the basis of their traits remain rare (Boukal 2014; but see Moretti et al. 2013).

Several ecosystem services, such as herbivore regulation, pollination and biogeochemical cycles, are dependent on multitrophic interactions, and there is an urgent need to improve our understanding of the relationships between plant and animal communities (Wood et al. 2015). The functioning of species-rich assemblages involved in interaction networks has been little studied to date and the mechanisms underlying the functioning of such assemblages remain poorly understood and quantified (Violle et al. 2014). Correlations have recently been found between the functional composition of vegetation and the abundance of phytophagous invertebrates in agroecosystems (Storkey et al. 2013) and natural habitats (Frenette-Dussault et al. 2013). Here, we extend the trait-based framework of Lavorel et al. (2013), which focused on trophic interactions, to non-trophic interactions, and we explain how it applies to conservation biological control in agroecosystems.

Our understanding of interactions between plant and animal communities and their effect on the biological control of pests remains limited. Conservation biological control aims to increase the abundance, diversity and efficacy of natural enemies through environmental management and the adoption of particular agricultural practices. Species-rich habitats, such as linear field margins between crop fields, support populations of the natural enemies of pests, and therefore help to improve the biological control of crop herbivores (Bischoff et al. 2016). Their effects are thought to be mediated by 
plant species composition (Haaland et al. 2011). The plant species found in these habitats provide functions not supplied by crop plants. This is obvious in natural enemies of crop herbivores that depend on specific plant resources at particular stages of their life cycle, such as hoverflies and parasitic wasps do. The role of plant species composition is less obvious for groups of natural enemies that do not feed on plants. For ground beetles, spiders and ground-dwelling arthropods, vegetation cover via structure-mediated effects is as important, or more, than resource-mediated effects (Balzan et al. 2016; Diehl et al. 2012).

If the implementation or the management of habitats to enhance functional biodiversity increases natural enemy populations, this does not necessarily result in a significant reduction of crop herbivores. The performance of these populations, in terms of biological control, depends on many other factors and interactions(Jonsson et al. 2008), and we are often unable to understand why some plant species mixtures perform better than other ones. There is also currently no methodology for knowledge transfer concerning the biological control efficiency of a given plant mixture to facilitate the choice of new sets of species adapted to other agronomic and climatic situations. Previous studies on trophic and non-trophic interactions within and between plant and animal communities focused principally on analyses of biological diversity through taxonomic approaches or on the global relationship between species diversity and community functioning (Snyder et al. 2006). Their results depended strongly on the species composition of the plant community studied (Wilby et al. 2013). A functional description of plant and arthropod communities is therefore required, to render findings more general and for the development of predictive agroecology.

Here, we review and discuss the contribution of a trait-based approach to improving our understanding of plant-arthropod interactions in agroecosystems, focusing on both trophic (e.g. arthropods feeding on plants, predators feeding on alternative prey) and non-trophic interactions. We address the following questions: (1) What characteristics of entomophagous arthropod communities are related to the regulation of crop herbivore populations? (2) Which functions and plants traits are involved in plantarthropod interactions? (3) How could the effects of plants on arthropod assemblages at community and landscape levels be scaled up, and what issues would this raise? 
125 For the preparation of this review, we searched the Web of Science literature database

126 (http://apps.webofknowledge.com) with two search strings in the "topic" search field. The first was

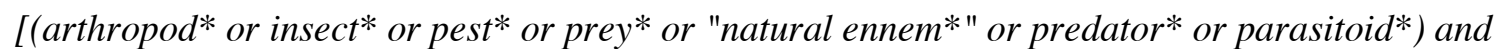

128 ("biological control" or biocontrol) and diversity and communit*], to target scientific articles

129 investigating the role of arthropod community structure in biological control. The second search string

130 was [("food web*" or "trophic network*" or "interaction network*") and (multitrophic or

131 interaction*) and (trait* or morpholog* or characteristic*) and (plant* or arthropod* or insect* or

132 flower*)], to target articles identifying traits involved in plant-arthropod interactions. Limiting our

133 search to articles published between 2005 and 2017 (last updated 29 $9^{\text {th }}$ November 2017), the two search

134 strings identified 507 and 528 articles, respectively. This first set of articles was analysed, and

135 additional relevant articles cited by these articles were added to the working set, whereas articles

136 considered to be outside the scope of the study were removed. We retained 515 articles for the final

137 analysis (Online Resource 1).

\section{The role of natural enemy diversity in controlling crop}

\section{0 herbivore communities}

141 The main properties of biological control and their relationship to the characteristics of

142 entomophagous arthropod communities emerging from the selected studies are summarized in Fig. 1

143 (first two columns). Crops harbour many herbivore species differing in terms of their taxonomic

144 identity and relative importance between years and between crop species. Interannual pest dynamics

145 and crop rotations make it necessary to consider interactions of herbivores and natural enemies at

146 community level. In general, control efficiency, for a large range of herbivore species, increases with

147 the diversity of natural enemies (Jonsson et al. 2017). Studies on predator and prey communities in

148 mesocosms have shown that the niche complementarity of predators is the principal mechanism

149 underlying the higher levels of predation in more diverse predator communities (Northfield et al.

150 2010; Wilby et al. 2005). The number and complementarity of functional groups of natural enemies,

151 rather than their taxonomic richness, thus appears to be the major determinant of the effect of 
diversity, when it exists.

153

154 By contrast, the stability of biological control for multispecies herbivore communities requires

155 functional diversity (i.e. diversity in the functions provided) and redundancy of natural enemies, which

156 should include both specialists and generalists (Gontijo et al. 2015), with no antagonistic interactions

157 (Fig. 1). Most relationships between community structure and functioning have been inferred from

158 experiments carried out in mesocosms, and their extrapolation to more complex communities under

159 field conditions is problematic. In croplands, habitat management is often used as a tool to support

160 beneficial insects (conservation biological control). It has been suggested that high levels of plant

161 diversity in non-crop habitats favour the amount of natural enemies, leading to a decrease in herbivore

162 abundance (Letourneau et al. 2011). However, little is known about the plant traits favouring effective

163 biological control and their interactions with arthropod communities. Below, we will review and

164 discuss current knowledge.

165

166

2. A trait-based approach to understanding plant-arthropod

167 interactions

\subsection{What functions must plant communities provide to promote herbivore} regulation within arthropod communities?

170 Plant community management to improve the efficiency of herbivore control by natural enemy

171 communities should have several objectives (third column in Fig. 1). Here, we focus on the case of the

172 neighbouring environment of the field, but our analysis also applies to within-field plant diversity. The

173 surrounding non-crop vegetation fulfils two main functions for the natural enemies of pests (detailed

174 in Fig. 1): it provides both trophic resources and shelter (Griffiths et al. 2008).

175

176 The abundance of several insect groups (e.g. Heteroptera, Syrphidae: Pfiffner and Wyss 2004)

177 increases with the total amount of resources available, whereas other groups of insects also respond to 
the diversity of these resources (Carabidae, Harwood et al. 2009). The resources supplied by plant

179 communities and required for completion of the life cycles of several natural enemies include nectar

180 and pollen for adults herbivores (hoverflies, parasitoids), and alternative prey for larval or adult

181 predators. The provision of trophic resources, such as floral nectar, increases the fecundity of some

182 parasitoids and, thus, the parasitism rates (Heimpel and Jervis 2005). Food resources must be

183 abundant, but also accessible and available at different times. Accessibility, such as the matching of

184 nectar depth in the corolla to the size of arthropod mouthparts, can be used as a criterion for targeting

185 specific arthropod natural enemies (Baggen et al. 1999). Plant communities could be designed to

186 improve the regulation of a large range of herbivores through the support of diverse groups of natural

187 enemies. The duration of the resource provisioning period is also crucial for both the maintenance of

188 entomophagous communities throughout the year, and to increase the growth rates of specialists

189 during pest outbreaks (Welch and Harwood 2014).

190 The role of vegetation in providing shelter has been little studied. Perennial plant communities, such

191 as beetle banks, provide refuges to protect populations of natural enemies against disturbances in the

192 vicinity of cropped habitats (MacLeod et al. 2004; Porcel et al. 2017). The density and complexity of

193 vegetation architecture and litter are important drivers of microclimate affecting vulnerable stages in

194 the life cycles of arthropods (oviposition, estivation, hivernation, Griffiths et al. 2008). Vegetation

195 provides attachment points for spider webs (MacLeod et al. 2004). Vegetation structure also

196 determines habitat complexity, thereby modifying interactions between natural enemies. It may reduce

197 intraguild predation by providing refuges and shelter, and reduce competition between natural enemies

198 from the same guild (Finke and Denno 2006; Wilby et al. 2013). However, studies investigating

199 resource- and structure-mediated effects have suggested that the provision of shelter and a favourable

200 microclimate affect the activity-density of arthropod generalist predators indirectly, by increasing

201 weed-borne resources or alternative prey (Birkhofer et al. 2008; Diehl et al. 2012).

203 Increases in the quantity and diversity of trophic resources may also affect crop pests, as demonstrated

204 for several lepidopteran herbivores (Balzan et al. 2016; Winkler et al. 2010). Plant communities

205 designed to enhance natural enemies should provide these populations with specific resources and

206 other habitat features not favourable to crop herbivores. 
208 Overall, plant communities can promote herbivore regulation by supplying diversified trophic 209 resources accessible to various arthropod species with mouthparts of different shapes and sizes. These 210 trophic resources should be available over a long period and should not be exploitable by unwanted 211 herbivores (Fig. 1). Many studies have been performed to investigate the provision, by plants, of floral 212 resources for parasitoids (e.g. Sivinski et al. 2011; Winkler et al. 2009) and hoverflies (van Rijn and 213 Wäckers 2010), and of overwintering habitats (Bürki and Hausammann 1992). A few of these studies

214 have shown that arthropod groups tend to be associated with particular functional traits of plant resources (e.g. Wäckers and van Rijn 2012). Most of the studies cited above focused specifically on particular species, and their results cannot be directly extrapolated to other plant-arthropod pairs.

217 Given the large number of possible interactions within and between arthropod communities, 218 alternative approaches are required to predict the functioning of these communities.

\subsection{Use of interaction traits to analyse relationships between plant and}

\section{arthropod communities}

The mechanisms underlying community assembly processes involve morphological, physiological, phenological and behavioural traits (sensu Pey et al. 2014; Violle et al. 2007). A role for morphological traits has been demonstrated in several plant-insect studies. For instance, pollination depends on the existence of a good match between insect proboscis length and the nectar holder depth of the corolla (Ibanez 2012; Stang et al. 2006). Grasshopper herbivory is mediated by a match between the toughness of plant leaves and insect mandibular strength (Ibanez et al. 2013). Pairs of response-and-effect traits must be identified, to improve resource provisioning to beneficial arthropods (Lavorel et al. 2013): plants modify arthropod performance via their effect traits, and the response of arthropods to the vegetation depends on their response traits. We will use the term

231 "interaction traits" to denote all traits mediating interactions between plants and animals.

233 Interaction traits include not only trophic (Lavorel et al. 2013), but also non-trophic interactions, such 
can modify feeding parameters (escape from predation), non-feeding parameters (mortality, reproduction) and dispersal. A well-known example of a non-trophic interaction is the presence of domatia in some plant species, providing specific habitats for arthropods, such as ants, to increase predation on herbivores and enhance plant defences (Agrawal and Karban 1997).

A trait-based approach, such as that recently used to predict the effect of various flower strips on hoverflies (van Rijn and Wäckers 2016), might improve the understanding and prediction of assemblages of invertebrate communities as a function of plant community composition (weed communities, semi-natural habitats, flower strips). Many studies have assessed the attractiveness of individual plant species to insects, but the identification of plant and animal interaction traits would make it possible to extrapolate findings to untested plant species. Despite the known effects of traits in mediating interactions, most ecological networks are still built on a taxonomic basis. Improvements in our understanding of interaction traits should facilitate the prediction of the role of these traits in structuring ecological networks and communities (Kissling and Schleuning 2015).

The mechanisms by which invertebrates affect other components of the ecosystem involve several interaction traits (Moretti et al. 2013). This is of great practical importance when the studied organisms are predators or parasitoids of agricultural pests. The relevant effect traits may be related to 253 diet, foraging behaviour, dispersal ability, shelter requirement and longevity.

\subsection{What are the key plant traits involved in plant-arthropod interactions?}

256 We will focus here on some key arthropod functional groups involved in biological control (soil dwellers, nectar and pollen feeders, leaf feeders, vegetation dwelling and flying predators).

\subsubsection{Plant traits associated with trophic interactions}

260 Studies on plant-herbivore and plant-pollinator interactions have identified several plant traits implied 261 in these interactions related to resource type, attractiveness, accessibility, quality and availability (Fig. 2). 
264 Resource type: Plants provide various food resources, such as leaves, stems, roots, fruits and seeds, 265 sap, floral and extrafloral nectar and pollen. They also indirectly provide honeydew and alternative 266 hosts and prey. Nectar and pollen have been studied mostly as resources for parasitoids, but these 267 resources are also consumed by various other insects and spiders (Chen et al. 2010). The availability 268 over time, quality and quantity of these resources constitute interaction traits that vary broadly among 269 plant species (Kühn et al. 2004). The carbohydrate and protein resources provided by plants increase 270 the longevity, reproduction and dispersal of their consumers (Wäckers et al. 2005). Fitness effects vary 271 considerably with the diet, sex and stage in the lifecycle of the arthropod consumer (Wäckers et al. 2007). Plants may act as occasional and supplementary food sources, but the resources they supply may also be of crucial importance, in synovigenic species of parasitoids for instance (Jervis et al.

274 2004), with nectar and pollen proteins have strong effects on adult performance and egg maturation.

Attractiveness of the resource: The presence of trophic resources does not necessarily imply that they are consumed. Olfactory, gustatory and visual signals facilitate the recognition and detection of resources, but may also be repellent, depending on the preferences of arthropod groups. Flowers emit olfactory signals and different species are not equally attractive to parasitoids (Belz et al. 2013).

280 Visual signals, such as plant height, flower height, inflorescence size and colour, are involved in 281 resource detection and a high degree of visual attractiveness increases the abundance of natural 282 enemies (Fiedler and Landis 2007).

283 For phytophagous insects feeding on plant tissues, secondary metabolites have a deterrent effect, 284 defending the plant against attack. In the Brassicaceae, glucosinolates act as defence compounds 285 against generalist herbivores, but may attract specialists (Fahey et al. 2001). This attractiveness to 286 specialists increases with specific glucosinolate content (Kos et al. 2014). Chemical traits are often 287 used to predict the relative attractiveness or repellent effects of plant species and genotypes, although 288 the effect of secondary metabolites on phytophagous insects varies considerably, and their role as 289 defence compounds has been called into question (Carmona et al. 2011).

290 Resource accessibility: Flower morphology, including corolla shape in particular, plays a crucial role 
in determining the accessibility of floral nectar and pollen (Heimpel and Jervis 2005). In flower-

visiting arthropods, head or body size may physically restrict access to floral resources in flowers with a small corolla diameter. In such cases, the plant-arthropod interaction depends on the length of the mouthparts. A correlation between nectar holder depth and the proboscis length of the flower visitor has been observed in several insect groups, especially in pollinators. Short corolla flowers favour hoverflies, whereas bumblebees prefer long corollas (Campbell et al. 2012). As a result, flower size is one of the most important variables determining the abundance and diversity of flower visitors and their size (Ibanez 2012; Stang et al. 2006; van Rijn and Wäckers 2016). By contrast, extrafloral nectar is generally produced on exposed nectaries, with no size constraints on its accessibility. However, extrafloral nectar has a higher sugar content than floral nectar, rendering it more viscous. This high viscosity facilitates the feeding of hymenopteran parasitoids, which have adapted mouthparts, but

302 limits the accessibility of this resource to lepidopterans, which feed only on dilute nectar (Géneau et 303 al. 2012).

In the herbivores serving as alternative prey for the natural enemies of pests, resource provisioning is dependent on plant palatability, which in turn depends on various morphological (e.g. presence of trichomes, Carmona et al. 2011), biomechanical and chemical traits (e.g. silica content, Massey et al. 2006). Plant resistance to chewing insects is positively related to leaf punch strength, work to shear and work to tear (Peeters et al. 2007). The incisor strength of insect mandibles is thus related to the traits of the leaves consumed (like leaf dry matter content and carbon:nitrogen ratio, Deraison et al. 2015). Biomechanical properties are associated with several leaf structure traits, such as cuticle thickness, lignin content, specific leaf area and leaf dry matter content (Pérez-Harguindeguy et al. 2003; Schädler et al. 2003). However, the effect of biomechanical properties may be partly

314 confounded with leaf nutrient quality (nitrogen content, carbon:nitrogen ratio, assimilate content), 315 which is negatively correlated with mechanical resistance (Peeters et al. 2007). 
and Jervis 2005). Floral nectar contains mostly sucrose, fructose and glucose (Baker and Baker 1983).

321 The sugar composition of nectar affects pollinator preferences. Parasitoids prefer floral nectar

322 composed predominantly of sucrose (Vattala et al. 2006), partly due to a gustatory response (Cocco

323 and Glendinning 2012). Extrafloral nectar generally has a higher sugar concentration, whereas

324 honeydew has a lower nutritional quality than nectar (Lee et al. 2004).

Temporal availability of resources: The synchrony between the plant and arthropod cycles determines the likelihood of interaction (Welch and Harwood 2014). The circadian rhythm of nectar production must coincide with the timing of flower and extrafloral nectaries visitors. The seasonal availability of resources depends on plant phenology. The phenological match between flowering period and arthropod floral resource requirements is crucial for completion of the life cycles of both herbivores 331 and their natural enemies.

332 A number of trophic interaction traits have, thus, been clearly identified (Fig. 2), and several traits

333 must be considered simultaneously in the evaluation of trophic interactions between plants and 334 arthropods.

\subsubsection{Plant traits associated with the non-resource functions of the habitat}

337 Plants have a number of other effects on invertebrates in addition to providing food (Fig. 2): physical

338 habitat provision, microclimate modification and habitat provision for all life stages, including the 339 most critical, such as reproduction.

341 The structural properties of non-crop vegetation, such as density, height and litter quantity, are known 342 to influence the distribution of soil-dwelling arthropods (Griffiths et al. 2008). Plant structural traits, 343 such as growth form, height, architecture (density and orientation of branches and leaves, leaf 344 morphology) and the presence of domatia shape arthropod habitats (Parolin et al. 2012). For example, 345 plant morphology influences small-scale invertebrate distribution: plants with a complex morphology 346 have higher invertebrate abundances and biomasses than plants with a simple morphology (Hansen et 347 al. 2010). At a smaller scale, the properties of plant surfaces, such as leaf toughness, epicuticular 348 waxes, pubescence and trichomes, affect the attachment and movement of arthropods, with contrasting 
effects on herbivores and predators, either enhancing or impairing biological control (Mitchell 2016; Petersen 2016).

Plants also provide epigeic invertebrates with shelter, particularly during the periods outside the crop growing season. The plant canopy maintains a moist microclimate and reduces wind speed (Norris and

354 Kogan 2005), protecting invertebrates from desiccation and providing favourable sites for aestivation.

355 Conversely, relatively dry sites with little temperature variation, such as grass tussocks, are favourable 356 sites for the overwintering of ground beetles (MacLeod et al. 2004). The role of plants in providing 357 suitable overwintering sites has been evaluated for a large range of plant and soil invertebrate species 358 (Bürki and Hausammann 1992), but the corresponding traits have yet to be identified, making it 359 difficult to draw general conclusions.

Habitat provision for reproduction, such as the choice of oviposition sites, has been analysed

362 principally in relation to adult and larval food distribution in the framework of optimal oviposition 363 theory (Wäckers et al. 2007). The olfactory stimuli emitted by plants, such as kairomones and 364 allomones, seem to predominate in the long-distance attraction or repulsion of gravid female 365 herbivores, whereas visual stimuli drive the choice of specific oviposition sites, limiting oviposition on 366 non-host plants (Hooks and Johnson 2003). Plants associated with higher egg survival rates are 367 suitable oviposition sites for phytophagous and predatory insects, and may be different from the plants 368 on which these insects feed (Norris and Kogan 2005). The physical characteristics of the plant are also 369 important. For example, hollow tree and shrub stems are selected as nesting sites for sphecid wasps 370 (Bitsch and Leclercq 1993). Nentwig (1992) recorded the oviposition preferences of lacewings on a 371 large range of plant species and found that oviposition rates were particularly high on plants of the 372 Papaveraceae and Boraginaceae species, possibly due to the pilosity of these species. However, it 373 remains unclear how plant traits, such as architecture or surface features (wax, pilosity etc.) affect the 374 oviposition behaviour of arthropods. 


\section{Scaling up to the community and landscape levels}

\subsection{Overcoming the limitations of single-species approaches}

Most studies on conservation biological control have focused on one or a few plant species and their role in the regulation of one or a few herbivore groups by one or a few natural enemies (e.g. Langoya and van Rijn 2008; Laubertie et al. 2012). Several of these studies have involved the screening of plants in controlled conditions to identify the most appropriate species for increasing the biocontrol performance of a particular natural enemy. The most frequently tested species are Phacelia tanacetifolia, Fagopyrum esculentum Moench and Lobularia maritima (L.) Desv.

However, crops are generally susceptible to attacks from several herbivore species. Moreover, in arable fields used for the cultivation of annual crops in rotation, a diverse community of natural enemies is required to regulate the associated communities of herbivores. The surrounding non-crop vegetation must, therefore, also consist of a mixture of plant species if it is to support a diverse community of natural enemies. However, plant effects on arthropod behaviour have been analysed mostly in pure stands, and little is known about the effect of plant assemblages (Pontin et al. 2006). In plant communities, attractive plant species may divert herbivores from less attractive species, resulting in lower visiting rates than for single-species stands. Interactions may also occur within arthropod communities, such as competition between an aggressive species and a less aggressive species (bee vs. hoverflies, Hogg et al. 2011). A greater diversity of plant resources and plant habitats may result in lower levels of competition and other negative interactions between arthropods, promoting a greater diversity of arthropods than would be expected from experimental results obtained for single-species stands. The occurrence of interactions makes it necessary to develop community-level approaches, to identify the characteristics of plant communities most likely to improve conservation biological control. Most studies to date have focused on a particular mixture (e.g. Gillespie et al. 2011; Pfiffner et al. 2009), but a small proportion of studies have compared different mixtures (eight studies out of 40 synthesized in Haaland et al. 2011).

However, there is strong evidence for functional relationships between plant and arthropod 
communities. The abundance of phytophagous invertebrates is positively correlated with plant traits related to resistance to community-level disturbances (e.g. low leaf dry matter content), suggesting a functional link between the two communities (Storkey et al. 2013). In addition to the mean trait values for plant communities, trait diversity may also be important. Potts et al. (2004) showed that the diversity of nectar resources was positively related to bee species richness.

\subsection{Which metrics provide information about the effects of plant community}

\section{structure on arthropod assemblages, and what are their limitations?}

In this section, we review the characteristics of plant communities relating to arthropod assemblages and their functioning in terms of herbivore regulation.

\section{Several descriptors can be used to characterise communities. The first is species identity. This} approach assumes that each species has an idiosyncratic role and that the functioning of the community depends on the particular species it contains. This view may reflect insufficient knowledge or an inadequate description of the mechanisms underlying the processes studied.

The second type of descriptor is based on the functional composition of the community. According to the biomass-ratio hypothesis, 'the extent to which the traits of a species affect ecosystem properties is likely to be strongly related to the contributions of the species [...]' to community biomass (Grime 1998). This suggests that the effects of plants on ecosystem functions are determined primarily by mean trait values at community level, weighted by the relative importance of each species. For example, in subalpine grasslands, the mean body mass of grasshoppers responds to the community weighted mean of leaf dry matter content (Moretti et al. 2013). The abundance of nectar- and pollenfeeding arthropods would be expected to increase with the amount of accessible resources provided by the whole plant community, possibly modulated by their nutritional value.

However, interactions between the functional components of the community may result in a community functioning that could not be inferred simply by adding together the effects of individual 
432

433

434

435

436

437

438

439

440

441

442

443

444

445

446

447

448

449

450

451

452

453

454

455

species. The ecosystem impact of organisms from higher trophic levels may be less related to abundance or biomass (Grime 1998) as in plants. Non-additive diversity effects can result from functional complementarity, which facilitates niche partitioning, or from synergistic or antagonistic interactions. Functional diversity is often measured as the diversity of functional traits and can be described by functional trait richness, evenness and divergence (Dias et al. 2013). In plant-invertebrate communities, a high diversity of plant resources and microhabitats would be expected to support a high diversity of invertebrates. Podgaiski et al. (2013) found a positive correlation between functional diversity in plant communities (in terms of size and architecture) and functional diversity in spiders (morphology and web-building type). However, this finding was not supported by those of other recent studies analysing the effects of the functional diversity of flower resources on natural enemies (Balzan et al. 2014; Uyttenbroeck et al. 2017). Due to the long generation times of several natural enemies, particularly for generalists, the temporal diversity of resource provisioning (e.g. flowering date and duration) may play an important role than the instantaneous diversity of flower resources.

There is no consensus concerning the relative importance of community species composition and functional structure (Costanzo and Barberi 2014), and the contribution of functional diversity effects to ecosystem functioning remains unclear (Gagic et al. 2015; Garibaldi et al. 2015; Garnier et al. 2016).

Recent meta-analyses have provided evidence that plant species diversity and functional diversity favour generalist predators (Dassou and Tixier 2016), thereby increasing herbivore regulation by natural enemies (Iverson et al. 2014). Several unanswered questions remain concerning the type of functional diversity (i.e. which traits?) and the degree of diversity optimising herbivore regulation.

\subsection{How is plant functional diversity related to herbivore regulation?}

457 It is not easy to determine the level of functional diversity required to optimise herbivore control at 458 community level. The biological control of a single herbivore species might be expected to depend 459 principally on the amounts of trophic resources and habitats supporting its main natural enemies 
(dominance effects). The plants traits supporting the natural enemies of additional herbivore species

461

462

463

464

465

466

467

468

469

470

471

472

473

474

475

476

477

478

479

480

481

482

483

484

485

may differ, resulting in a need for diverse plant functions to support the entire natural enemy community required to regulate a community of herbivores. As shown by Isbell et al. (2011), the larger the number of ecosystem services required of plant communities, the larger the number of plants with different functions is needed to provide those services. However, in a plant community of fixed size, plant functional diversity cannot be increased in isolation, without modifying other community properties.

First, the generally hump-shaped relationship between the community weighted mean of traits (CWM) and functional diversity (Dias et al. 2013) implies that, for any given trait, functional diversity tends to be lowest at extreme values of CWM. Thus, depending on the plant trait values related to biological control, this interdependence may constrain increases in functional diversity.

Second, evenness, which is a component of functional diversity, reduces dominance effects by diluting the relative contribution of dominant species within the community. For example, combining plant species according to their flowering period, so as to ensure that nectar and pollen are supplied throughout the year, decreases the density of plants flowering at the same time. At peak flowering, more resources are available in communities with a homogeneous phenology than in communities with a heterogeneous phenology, resulting in a trade-off between the diversity of resources and their instantaneous availability. Thus, increasing the diversity of plant traits to increase the diversity of arthropods may result in a lower density of each type of arthropod.

This trade-off between evenness and dominance effects suggests that the functional diversitybiological control relationship may not be monotonous. Provided that plant functional diversity promotes complementarity and positive interactions with natural enemies, this should counterbalance the decrease in plant dominance effects. Thus, the functional diversity-herbivore regulation relationship may not always be positive, and may reach a plateau or an optimum value, depending on the strength of the synergistic interactions at high levels of plant functional diversity. The deciphering of this relationship will require experiments in which the functional composition and diversity of plant 
communities are varied, for the simultaneous testing of the two effects, and for quantitative analyses of the relationships between functional trait diversity, composition and ecosystem functions.

Several traits (Fig. 2) and metrics have been proposed to account for the interactions between species or between restricted taxonomic groups. The next step is the identification of combinations of plant community metrics accounting for the effects of the plant community on arthropod communities, and taking into account the effects of functional composition, functional diversity and species identity (when effects cannot be related to functional traits). The level of functional redundancy is another important aspect.

\subsection{Taking interactions with surrounding landscapes into account}

The management of a given habitat for conservation biological control must be adapted to the characteristics of the neighbouring habitats, such as crop fields and other non-crop structures (Tscharntke et al. 2016). The creation of a new habitat, such as a wildflower strip, provides additional resources and habitats. Plant community management or establishment should therefore be based on i) assessments of the requirements of natural enemies and ii) assessments of the resources already provided in the surroundings, in locally limiting resources or habitats. For instance, the effect of wildflower strips on pollinators depends strongly on their complementarity with the resources already available at landscape scale (Scheper et al. 2015), particularly as concerns synchrony between flowering period and pollinator requirements. Plant traits must be adapted to abiotic conditions, such as climate and soil conditions. In arid climates, arthropods may search for moist shelters protecting them from drought stress (tussocks and creeping plants providing shade and higher levels of humidity), whereas, in humid climates, open habitats with rapid warming may result in higher levels of arthropod activity. A functional characterisation of the surrounding landscape (functional landscape ecology) is therefore required, with an improvement of the metrics of landscape description beyond land use (Vialatte 2017; landscape ecology). Simplified vegetation relevés, stratified by habitat type, can be used to calculate the landscape-wide floral resource availability (Scheper 2015). This approach could be extended to other plant properties, including habitat-related traits, and other metrics, such as 
517 the spatial diversity of plant trait values. In the future, such descriptions of the properties of plant

518 communities at the landscape scale should make it possible to adapt habitat creation and management,

519 to improve spatial functional supplementation and complementation rather than making use of

520 standardised greening infrastructures.

521

522 Conclusions and implications for conservation biological

\section{3 control}

524 A trait-based approach opens up exciting new possibilities for improving our understanding of the

525 relationships between plant assemblages and conservation biological control. The well-known

526 influence of morphological and biochemical traits on the interaction between plants and pollinators

527 (Stang et al. 2009) suggests that this approach may also be useful for dealing with other biotic

528 interactions.

529

530 We also need to identify the characteristics of arthropod communities associated with efficient

531 biological control. Despite the general finding that the stable biological control of multispecies

532 herbivore communities requires functional diversity and a redundancy of natural enemies, the

533 development of appropriate management practices remains limited by our poor understanding of the

534 functioning of arthropod communities, and of their trophic interaction network, in particular.

536 We also propose the identification of "interaction traits" specifically involved in plant-arthropod

537 interactions, including the effect traits of plants (traits with an impact on arthropods) and the response

538 traits of arthropods (traits associated with the arthropod response to plants). Interaction traits are

539 correlated with plant features relating to the provision of trophic resources (amount of resource,

540 phenology of production, corolla shape etc.) and habitat (plant architecture) affecting arthropods (Fig.

541 2). Important interaction traits, such as nectar composition, extrafloral nectar availability, presence of

542 domatia and plant pilosity, are currently poorly documented in botanical databases. The use of such

543 traits would improve our mechanistic understanding of interactions at community level. It might also 
make it possible to quantify the diversity and redundancy of interaction traits in plant communities and to determine their relationship to the abundance of natural enemies or herbivore regulation.

We need to scale up our knowledge of plant-arthropod interactions, from the population to the community level. The extent to which arthropod communities are affected by plant traits at community level remains largely unexplored. An intermediate level of plant functional diversity might be expected to maximise the service of herbivore regulation, but experimental designs facilitating the comparison of contrasting plant communities (such as Hatt et al. 2017) will be useful for disentangling the respective roles of plant functional composition and diversity.

The identification of relevant community characteristics should not be limited to additive species traits. It should also take into account the structure of the interaction network, species complementarity and the generalist/specialist ratio.

Over and above the identification of relevant plant traits, the high specificity of certain plant-insect and insect-insect interactions may weaken the trait-based approach. Aphid-parasitoid and plant-aphid interactions are usually species-specific. Consequently, aphid regulation often requires the targeting of a particular aphid species by promoting a particular parasitoid species. Trade-offs may occur between

562 the positive effects of plant traits on one group of natural enemies and negative effects on another. It 563 therefore seems likely that some sets of traits are related to herbivore regulation in general, but we 564 cannot exclude the possibility that these combinations are highly specific and that a trait-based approach is not necessarily more straightforward than a species-based approach. We do not, therefore, recommend the exclusive use of trait-based approaches, and advances in food-web ecology will undoubtedly also improve the understanding and management of trophic interactions. If interactions

568 are idiosyncratic or poorly understood, and if trait attributes are phylogenetically conserved, then 569 phylogenetic parameters may be better predictors of ecosystem functioning than functional traits or 570 groups (Cadotte et al. 2008). However, interaction specificity usually includes a single dimension of a 571 niche, and a trait-based approach may still be straightforward for the other dimensions. For generalist predators, a trait-based approach would remain relevant, but difficulties may arise due to the number 
of traits and their interactions to be considered in each situation to predict their functioning. If patterns

574 become too complex and difficult to generalize, then the trait-based approach may be impractical.

576 In practice, interaction traits may be used to decide on the combinations of plant properties required to

577 guide the formulation of seed mixtures for creating or restoring semi-natural habitats, rather than using

578 standard species lists applied to several biogeographical zones. The identification of plant species from

579 the local flora with the desired trait criteria would make it possible to design seed mixtures with

580 similar functional characteristics based on species adapted to local climatic conditions.

582 The use of functional traits as proxies for community and ecosystem functioning should not completely supplant other drivers of plant arthropod interactions, such as environmental conditions and habitat management. In addition, the use of plant communities to support biological control must also take into account a diversity of ecological, technical and socio-economic criteria, such as a potential loss of diversity during plant succession.

Problematic weed species cannot be included in the mixtures sown, even if they present ideal trait combinations. Plant species of local origin should be preferred whenever possible, to select locally adapted populations and to prevent genetic pollution. Finally, trade-offs with other ecosystem services

591 should be considered from a multifunctional standpoint, including pollination, species conservation 592 and landscape aesthetics.

597 Conflict of interest: The authors have no conflict of interest to declare. 
601 Agrawal AA, Karban R (1997) Domatia mediate plant-arthropod mutualism Nature 387:562-563 602 doi:10.1038/42384

603 Baggen LR, Gurr GM, Meats A (1999) Flowers in tri-trophic systems: mechanisms allowing selective 604 exploitation by insect natural enemies for conservation biological control Entomol Exp Appl 91:155605161 doi:10.1046/j.1570-7458.1999.00478.x

606 Baker HG, Baker I (1983) Floral nectar sugar constituents in relation to pollinator type Handbook of 607 experimental pollination biology:117-141

608 Balzan M, Bocci G, Moonen A-C (2014) Augmenting flower trait diversity in wildflower strips to 609 optimise the conservation of arthropod functional groups for multiple agroecosystem services J Insect 610 Conserv 18:713-728 doi:10.1007/s10841-014-9680-2

611 Balzan MV, Bocci G, Moonen AC (2016) Utilisation of plant functional diversity in wildflower strips 612 for the delivery of multiple agroecosystem services Entomol Exp Appl 158:304-319 613 doi:10.1111/eea.12403

614 Belz E, Kölliker M, Balmer O (2013) Olfactory attractiveness of flowering plants to the parasitoid 615 Microplitis mediator: potential implications for biological control Biocontrol 58:163-173 616 doi:10.1007/s10526-012-9472-0

617 Birkhofer K et al. (2017) Land-use type and intensity differentially filter traits in above- and below618 ground arthropod communities J Anim Ecol 86:511-520 doi:10.1111/1365-2656.12641

619 Birkhofer K, Wise DH, Scheu S (2008) Subsidy from the detrital food web, but not microhabitat 620 complexity, affects the role of generalist predators in an aboveground herbivore food web Oikos 621 117:494-500 doi:10.1111/j.0030-1299.2008.16361.x

622 Bischoff A et al. (2016) Effects of spontaneous field margin vegetation and surrounding landscape on 623 Brassica oleracea crop herbivory Agr Ecosyst Environ 223:135-143 624 doi:http://dx.doi.org/10.1016/j.agee.2016.02.029

625 Bitsch J, Leclercq J (1993) Hyménoptères Sphecidae d'Europe Occidentale, volume I. Faune de France 626 79. Fédération Française des Sociétés de Sciences Naturelles, Paris, France,

627 Boukal DS (2014) Trait- and size-based descriptions of trophic links in freshwater food webs: current 628 status and perspectives J Limnol 73:171-185 doi:10.4081/jlimnol.2014.826

629 Bürki H-M, Hausammann A (1992) Überwinterung von Arthropoden im Boden und an Ackerkraütern 630 künstlich angelegter Ackerkrautstreifen Agrarökologie 7:1-158

631 Cadotte MW, Cardinale BJ, Oakley TH (2008) Evolutionary history and the effect of biodiversity on 632 plant productivity Proc Natl Acad Sci U S A 105:17012-17017 doi:10.1073/pnas.0805962105

633 Campbell AJ, Biesmeijer JC, Varma V, Wäckers FL (2012) Realising multiple ecosystem services 634 based on the response of three beneficial insect groups to floral traits and trait diversity Basic and 635 Applied Ecology 13:363-370 doi:10.1016/j.baae.2012.04.003 
640 Cocco N, Glendinning JI (2012) Not all sugars are created equal: some mask aversive tastes better 013-0178-1

Dassou AG, Tixier P (2016) Response of pest control by generalist predators to local-scale plant diversity: a meta-analysis Ecology and Evolution 6:1143-1153 doi:10.1002/ece3.1917

647 Deraison H, Badenhausser I, Loeuille N, Scherber C, Gross N (2015) Functional trait diversity across trophic levels determines herbivore impact on plant community biomass Ecology Letters 18:13461355 doi:10.1111/ele.12529

650 Dias ATC, Berg MP, de Bello F, Van Oosten AR, Bílá K, Moretti M (2013) An experimental 651 framework to identify community functional components driving ecosystem processes and services delivery J Ecol 101:29-37 doi:10.1111/1365-2745.12024

Diehl E, Wolters V, Birkhofer K (2012) Arable weeds in organically managed wheat fields foster carabid beetles by resource- and structure-mediated effects Arthropod-Plant Interactions 6:75-82 doi:10.1007/s11829-011-9153-4

Fahey JW, Zalcmann AT, Talalay P (2001) The chemical diversity and distribution of glucosinolates and isothiocyanates among plants Phytochemistry 56:5-51 doi:10.1016/s0031-9422(00)00316-2

Fiedler AK, Landis DA (2007) Plant characteristics associated with natural enemy abundance at Michigan native plants Environ Entomol 36:878-886 doi:10.1603/0046$225 x(2007) 36[878$ :pcawne]2.0.co;2

661 Finke DL, Denno RF (2006) Spatial refuge from intraguild predation: implications for prey 662 suppression and trophic cascades Oecologia 149:265-275 doi:10.1007/s00442-006-0443-y

663 Frenette-Dussault C, Shipley B, Hingrat Y (2013) Linking plant and insect traits to understand 664 multitrophic community structure in arid steppes Funct Ecol 27:786-792 doi:10.1111/1365$665 \quad 2435.12075$

666 Gagic V et al. (2015) Functional identity and diversity of animals predict ecosystem functioning better 667 than species-based indices Proc R Soc B 282:sous presse doi:10.1098/rspb.2014.2620

668 Garibaldi LA et al. (2015) Trait matching of flower visitors and crops predicts fruit set better than trait 669 diversity J Appl Ecol 52:1436-1444 doi:10.1111/1365-2664.12530

670 Garnier É, Navas M-L, Grigulis K (2016) Plant functional diversity. Oxford University Press, United 671 Kingdom, 

control of cabbage pests by parasitoids Basic and Applied Ecology 13:85-93 doi:10.1016/j.baae.2011.10.005

Gillespie M, Wratten S, Sedcole R, Colfer R (2011) Manipulating floral resources dispersion for hoverflies (Diptera: Syrphidae) in a California lettuce agro-ecosystem Biol Control 59:215-220 doi:10.1016/j.biocontrol.2011.07.010

Gontijo LM, Beers EH, Snyder WE (2015) Complementary suppression of aphids by predators and parasitoids Biol Control 90:83-91 doi:10.1016/j.biocontrol.2015.06.002

Griffiths GJK, Holland JM, Bailey A, Thomas MB (2008) Efficacy and economics of shelter habitats for conservation biological control Biol Control 45:200-209 doi:10.1016/j.biocontrol.2007.09.002

Grime JP (1998) Benefits of plant diversity to ecosystems: immediate, filter and founder effects J Ecol 86:902-910

Haaland C, Naisbit RE, Bersier LF (2011) Sown wildflower strips for insect conservation: a review Insect Conservation and Diversity 4:60-80 doi:10.1111/j.1752-4598.2010.00098.x

Hansen JP, Sagerman J, Wikstrom SA (2010) Effects of plant morphology on small-scale distribution of invertebrates Mar Biol 157:2143-2155 doi:10.1007/s00227-010-1479-4

Harwood JD et al. (2009) Invertebrate biodiversity affects predator fitness and hence potential to control pests in crops Biol Control 51:499-506 doi:10.1016/j.biocontrol.2009.09.007

Hatt $\mathrm{S}$ et al. (2017) Do flower mixtures with high functional diversity enhance aphid predators in wildflower strips? Eur J Entomol 114:66-76 doi:10.14411/eje.2017.010

Heimpel GE, Jervis MA (2005) Does floral nectar improve biological control by parasitoids? In: Wäckers F, van Rijn P, Bruin J (eds) Plant-provided food and plant-carnivore mutualism. Cambridge University Press, Cambridge, UK, pp 267-304

Hogg BN, Bugg RL, Daane KM (2011) Attractiveness of common insectary and harvestable floral resources to beneficial insects Biol Control 56:76-84 doi:10.1016/j.biocontrol.2010.09.007

Hooks CRR, Johnson MW (2003) Impact of agricultural diversification on the insect community of cruciferous crops Crop Prot 22:223-238 doi:10.1016/s0261-2194(02)00172-2

Ibanez S (2012) Optimizing size thresholds in a plant-pollinator interaction web: towards a mechanistic understanding of ecological networks Oecologia 170:233-242 doi:10.1007/s00442-0122290-3

Ibanez S, Lavorel S, Puijalon S, Moretti M (2013) Herbivory mediated by coupling between biomechanical traits of plants and grasshoppers Funct Ecol 27:479-489 doi:10.1111/1365-2435.12058

Isbell F et al. (2011) High plant diversity is needed to maintain ecosystem services Nature 477:199U196 doi:10.1038/nature10282

Iverson AL et al. (2014) Do polycultures promote win-wins or trade-offs in agricultural ecosystem services? A meta-analysis J Appl Ecol 51:1593-1602 doi:10.1111/1365-2664.12334 
Jervis MA, Lee JC, Heimpel GE (2004) Use of behavioural and life-history studies to understand the effects of habitat manipulation. In: Gurr GM, Wratten SD, Altieri MA (eds) Ecological engineering for pest management. CSIRO, Wallingford, UK, pp 65-100

Jonsson M, Kaartinen R, Straub CS (2017) Relationships between natural enemy diversity and biological control Current Opinion in Insect Science 20:1-6 doi:10.1016/j.cois.2017.01.001

Jonsson M, Wratten SD, Landis DA, Gurr GM (2008) Recent advances in conservation biological control of arthropods by arthropods Biol Control 45:172-175 doi:10.1016/j.biocontrol.2008.01.006

Kissling WD, Schleuning M (2015) Multispecies interactions across trophic levels at macroscales: retrospective and future directions Ecography 38:346-357 doi:10.1111/ecog.00819

Kos $\mathrm{M}$ et al. (2014) Relative importance of plant-mediated bottom-up and top-down forces on herbivore abundance on Brassica oleracea Funct Ecol 25:1113-1124 doi:10.1111/j.13652435.2011.01871.x

Kühn I, Durka W, Klotz S (2004) BiolFlor - a new plant-trait database as a tool for plant invasion ecology Divers Distrib 10:363-365

Langoya LA, van Rijn PCJ (2008) The significance of floral resources for natural control of aphids Proceedings of the Netherlands Entomological Society Meeting 19:67-74

Laubertie EA, Wratten SD, Hemptinne JL (2012) The contribution of potential beneficial insectary plant species to adult hoverfly (Diptera: Syrphidae) fitness Biol Control 61:1-6 doi:10.1016/j.biocontrol.2011.12.010

Lavorel S et al. (2011) Using plant functional traits to understand the landscape distribution of multiple ecosystem services J Ecol 99:135-147 doi:10.1111/j.1365-2745.2010.01753.x

Lavorel S et al. (2013) A novel framework for linking functional diversity of plants with other trophic levels for the quantification of ecosystem services J Veg Sci 24:942-948 doi:10.1111/jvs.12083

Lee JC, Heimpel GE, Leibee GL (2004) Comparing floral nectar and aphid honeydew diets on the longevity and nutrient levels of a parasitoid wasp Entomol Exp Appl 111:189-199 doi:10.1111/j.00138703.2004.00165.x

Letourneau DK et al. (2011) Does plant diversity benefit agroecosystems? A synthetic review Ecological Applications 21:9-21 doi:10.1890/09-2026.1

MacLeod A, Wratten SD, Sotherton NW, Thomas MB (2004) 'Beetle banks' as refuges for beneficial arthropods in farmland: long-term changes in predator communities and habitat Agric For Entomol 6:147-154 doi:10.1111/j.1461-9563.2004.00215.x

Massey FP, Ennos AR, Hartley SE (2006) Silica in grasses as a defence against insect herbivores: contrasting effects on folivores and a phloem feeder J Anim Ecol 75:595-603 doi:10.1111/j.13652656.2006.01082.x

Moretti M et al. (2013) Linking traits between plants and invertebrate herbivores to track functional effects of land-use changes J Veg Sci 24:949-962 doi:10.1111/jvs.12022 
Norris RF, Kogan M (2005) Ecology of interactions between weeds and arthropods. In: Annual 503. doi:10.1146/annurev.ento.49.061802.123218

Northfield TD, Snyder GB, Ives AR, Snyder WE (2010) Niche saturation reveals resource partitioning among consumers Ecology Letters 13:338-348 doi:10.1111/j.1461-0248.2009.01428.x

Parolin P, Bresch C, Poncet C, Desneux N (2012) Functional characteristics of secondary plants for increased pest management Int J Pest Manage 58:368-376 doi:10.1080/09670874.2012.734869

Peeters PJ, Sanson G, Read J (2007) Leaf biomechanical properties and the densities of herbivorous insect guilds Funct Ecol 21:246-255 doi:10.1111/j.1365-2435.2006.01223.x

Pérez-Harguindeguy N, Díaz S, Vendramini F, Cornelissen JHC, Gurvich DE, Cabido M (2003) Leaf traits and herbivore selection in the field and in cafeteria experiments Austral Ecol 28:642-650 doi:10.1046/j.1442-9993.2003.01321.x

Pey B et al. (2014) Current use of and future needs for soil invertebrate functional traits in community ecology Basic and Applied Ecology 15:194-206 doi:10.1016/j.baae.2014.03.007

Pfiffner L, Luka H, Schlatter C, Juen A, Traugott M (2009) Impact of wildflower strips on biological control of cabbage lepidopterans Agr Ecosyst Environ 129:310-314 doi:10.1016/j.agee.2008.10.003

Pfiffner L, Wyss E (2004) Use of sown wildflower strips to enhance natural enemies of agricultural pests. In: Ecological engineering for pest management: advances in habitat manipulation for arthropods. CABI Publishing, Wallingford, UK, pp 165-186

Podgaiski LR, Joner F, Lavorel S, Moretti M, Ibanez S, Mendonca MD, Pillar VD (2013) Spider trait assembly patterns and resilience under fire-induced vegetation change in South Brazilian grasslands PLoS One 8:11 doi:10.1371/journal.pone.0060207

Pontin DR, Wade MR, Kehrli P, Wratten SD (2006) Attractiveness of single and multiple species flower patches to beneficial insects in agroecosystems Ann Appl Biol 148:39-47 doi:10.1111/j.17447348.2005.00037.x

Porcel M, Cotes B, Castro J, Campos M (2017) The effect of resident vegetation cover on abundance and diversity of green lacewings (Neuroptera: Chrysopidae) on olive trees J Pest Sci 90:195-206 doi:10.1007/s10340-016-0748-5

Potts SG, Vulliamy B, Roberts S, O'Toole C, Dafni A, Ne'eman G, Willmer PG (2004) Nectar resource diversity organises flower-visitor community structure Entomol Exp Appl 113:103-107 doi:10.1111/j.0013-8703.2004.00212.x

Schädler M, Jung G, Auge H, Brandl R (2003) Palatability, decomposition and insect herbivory: patterns in a successional old-field plant community Oikos 103:121-132 doi:10.1034/j.16000706.2003.12659.x

Scheper J et al. (2015) Local and landscape-level floral resources explain effects of wildflower strips 
Sivinski J, Wahl D, Holler T, Al Dobai S, Sivinski R (2011) Conserving natural enemies with flowering plants: Estimating floral attractiveness to parasitic Hymenoptera and attraction's relationship to flower and plant morphology Biol Control 58:208-214 doi:10.1016/j.biocontrol.2011.05.002

Snyder WE, Snyder GB, Finke DL, Straub CS (2006) Predator biodiversity strengthens herbivore suppression Ecology Letters 9:789-796 doi:10.1111/j.1461-0248.2006.00922.x

Stang M, Klinkhamer PGL, van der Meijden E (2006) Size constraints and flower abundance determine the number of interactions in a plant-flower visitor web Oikos 112:111-121 doi:10.1111/j.0030-1299.2006.14199.x

Stang M, Klinkhamer PGL, Waser NM, Stang I, van der Meijden E (2009) Size-specific interaction patterns and size matching in a plant-pollinator interaction web Ann Bot 103:1459-1469 doi:10.1093/aob/mcp027

Storkey J, Brooks D, Haughton A, Hawes C, Smith BM, Holland JM (2013) Using functional traits to quantify the value of plant communities to invertebrate ecosystem service providers in arable landscapes J Ecol 101:38-46 doi:10.1111/1365-2745.12020

Tscharntke $\mathrm{T}$ et al. (2016) When natural habitat fails to enhance biological pest control - Five hypotheses Biol Conserv 204:449-458 doi:10.1016/j.biocon.2016.10.001

Uyttenbroeck R, Piqueray J, Hatt S, Mahy G, Monty A (2017) Increasing plant functional diversity is not the key for supporting pollinators in wildflower strips Agr Ecosyst Environ 249:144-155 doi:10.1016/j.agee.2017.08.014

van Rijn PCJ, Wäckers FL (2010) The suitability of field margin flowers as food sources for zoophagous hoverflies Landscape management for functional biodiversity 56:125-128

van Rijn PCJ, Wäckers FL (2016) Nectar accessibility determines fitness, flower choice and abundance of hoverflies that provide natural pest control J Appl Ecol:n/a-n/a doi:10.1111/13652664.12605

Vattala HD, Wratten SD, Phillips CB, Wäckers FL (2006) The influence of flower morphology and nectar quality on the longevity of a parasitoid biological control agent Biol Control 39:179-185 doi:10.1016/j.biocontrol.2006.06.003

Violle C, Navas ML, Vile D, Kazakou E, Fortunel C, Hummel I, Garnier E (2007) Let the concept of trait be functional! Oikos 116:882-892

Violle C, Reich PB, Pacala SW, Enquist BJ, Kattge J (2014) The emergence and promise of functional biogeography Proceedings of the national academy of sciences 111:13690-13696 doi:10.1073/pnas.1415442111

Wäckers FL, Romeis J, van Rijn P (2007) Nectar and pollen feeding by insect herbivores and implications for multitrophic interactions. In: Annual Review of Entomology, vol 52. Annual Review of Entomology. Annual Reviews, Palo Alto, pp 301-323. doi:10.1146/annurev.ento.52.110405.091352

Wäckers FL, van Rijn PCJ (2012) Pick and mix: selecting flowering plants to meet the requirements 
818 of target biological control insects. In: Biodiversity and Insect Pests. John Wiley \& Sons, Ltd, pp 139-

819 165. doi:10.1002/9781118231838.ch9

820 Wäckers FL, van Rijn PCJ, Bruin J (2005) Plant-provided food for carnivorous insects. Cambridge

821 University Press, Cambridge, UK,

822 Welch KD, Harwood JD (2014) Temporal dynamics of natural enemy-pest interactions in a changing 823 environment Biol Control 75:18-27 doi:10.1016/j.biocontrol.2014.01.004

824 Wilby A, Anglin LA, Nesbit CM (2013) Plant species composition alters the sign and strength of an 825 emergent multi-predator effect by modifying predator foraging behaviour PLoS One 8:7 826 doi:10.1371/journal.pone.0070258

827 Wilby A, Villareal SC, Lan LP, Heong KL, Thomas MB (2005) Functional benefits of predator 828 species diversity depend on prey identity Ecol Entomol 30:497-501 doi:10.1111/j.0307$829 \quad 6946.2005 .00717 . x$

830 Winkler K, Wackers FL, Kaufman LV, Larraz V, van Lenteren JC (2009) Nectar exploitation by 831 herbivores and their parasitoids is a function of flower species and relative humidity Biol Control 832 50:299-306 doi:10.1016/j.biocontrol.2009.04.009

833 Winkler K, Wackers FL, Termorshuizen AJ, van Lenteren JC (2010) Assessing risks and benefits of 834 floral supplements in conservation biological control Biocontrol 55:719-727 doi:10.1007/s10526-010$835 \quad 9296-8$

836 Wood SA, Karp DS, DeClerck F, Kremen C, Naeem S, Palm CA (2015) Functional traits in 837 agriculture: agrobiodiversity and ecosystem services Trends in Ecology \& Evolution 30:531-539 838 doi:10.1016/j.tree.2015.06.013

839 Wratten SD, Gillespie M, Decourtye A, Mader E, Desneux N (2012) Pollinator habitat enhancement: 840 benefits to other ecosystem services Agr Ecosyst Environ 159:112-122 841 doi:10.1016/j.agee.2012.06.020

842 


\section{Figures and online resource}

844

845 Fig. 1 Outline of the main objectives targeted for efficient conservation biological control (first

846 column), their effects on arthropod community functioning (second column) and on plant community

847 and habitat management (third column), synthesised from published findings.

848

849 Fig. 2 Overview of the main plant-arthropod interaction traits recorded in published studies and

850 relevant for managing arthropod communities by conservation biological control. Heracleum

851 sphondylium image $\mathbb{C}$ Pierre Déom - www.lahulotte.fr

852

853 Online Resource 1. List of the articles selected with the search equation in the Web of Science

854 literature database and used for the review. 


\section{Improving conservation biological control by enhancing...}

.... the intensity of biological control

$\ldots$ the regulation of herbivore communities

...the temporal stability of regulation

\section{Expected arthropod community functioning}

Increase the abundance

entomophagous arthropods

of

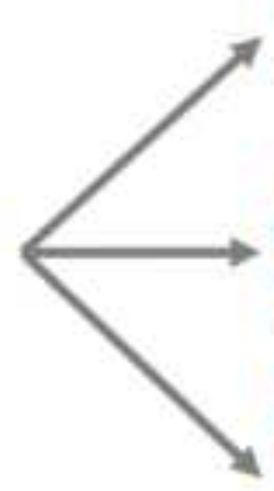

Increase entomophagous arthropods

in the crop field by enhancing their spillover from semi-natural habitats

Consequences for plant communities management

Increase the carrying capacity by $\rightarrow$ providing non-limiting amounts of trophic resources and other habitat functions

Adopt crop management favouring beneficial arthropods in the field (habitat provision)

Manage positive and negative interactions between arthropods to maintain high densities of predators and a high regulation

Optimisation of habitat structural complexity

Foster a functional diversity of entomophagous arthropods improving niche complementarity and mutualism

Avoid the attraction of crop herbivores that may switch to the crops

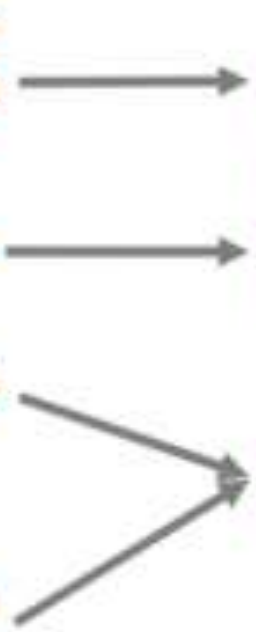
Increase the diversity of trophic resources

Provide selective resources enhancing desired arthropods but not crop herbivores

Enhance the abundance of generalist predators with a wide feeding niche

Provide plants hosting alternative prey that are not crop herbivores

Facilitate early season regulation in particular by generalist predators

Maintain high densities of entomophagous arthropods during all seasons
Provide trophic resources throughout the whole year to prevent the collapse of predator populations 


\section{Plant traits}

Traits associated with trophic interactions

Resource type (nectar, pollen, seeds, leaves) and quantity

Attractiveness: odour, taste, inflorescence size and colour, secondary metabolites

Accessibility: flower shape

Nutritional quality : sugar composition, leaf structural traits

Phenology: flowering date, duration, timing of resource production

\section{Traits associated with non- resource habitat functions}

Physical habitat provision: domatia, hollow stems, pilosity

Architecture: height, growth form, vertical leaf distribution

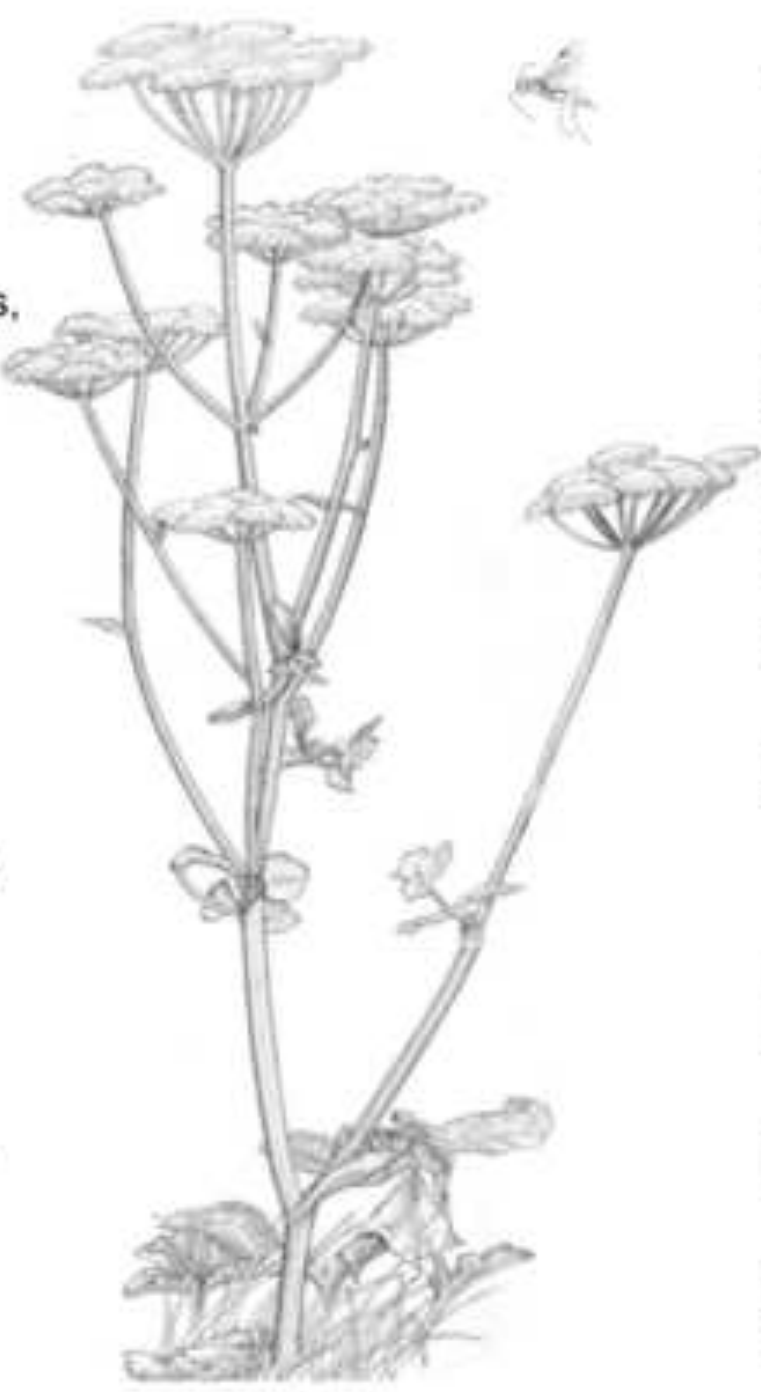

\section{Arthropod traits}

Traits associated with trophic interactions

Trophic level, diet and specific food requirements at different life-cycle stages

Food preferences, ovigeny, mouthparts structure

Body size, head width

Phenology: voltinism, breeding season, emergence season

\section{Traits associated with non- resource habitat functions}

Mobility, body size, dispersal mode, hunting strategy, sociality

Ecological preferences for overwintering, aestivation, oviposition 


\title{
Understanding plant-arthropod interactions in multitrophic communities to improve conservation biological control: useful traits and metrics
}

\author{
Journal of Pest Science
}

Antoine Gardarin, Manuel Plantegenest, Armin Bischoff and Muriel Valantin-Morison

Corresponding author: UMR Agronomie, INRA, AgroParisTech, Université Paris-Saclay, 78850 Thiverval-Grignon, France. Antoine.Gardarin@inra.fr.

Online Resource 1. List of the articles selected from the search equation in the Web of Science literature database and used for the review.

Abbas M, Klein AM, Ebeling A, Oelmann Y, Ptacnik R, Weisserg WW, Hillebrand H (2014) Plant diversity effects on pollinating and herbivorous insects can be linked to plant stoichiometry Basic and Applied Ecology 15:169-178 doi:10.1016/j.baae.2014.02.001

Agelopoulos N et al. (1999) Exploiting semiochemicals in insect control Pestic Sci 55:225-235

Agrawal AA, Karban R (1997) Domatia mediate plant-arthropod mutualism Nature 387:562-563 doi:10.1038/42384

Agustí N, Shayler SP, Harwood JD, Vaughan IP, Sunderland KD, Symondson WOC (2003) Collembola as alternative prey sustaining spiders in arable ecosystems: prey detection within predators using molecular markers Mol Ecol 12:3467-3475 doi:10.1046/j.1365-294X.2003.02014.x

Al-Dobai S, Reitz S, Sivinski J (2012) Tachinidae (Diptera) associated with flowering plants: estimating floral attractiveness Biol Control 61:230-239 doi:10.1016/j.biocontrol.2012.02.008

Alhmedi A, Haubruge E, D'Hoedt S, Francis F (2011) Quantitative food webs of herbivore and related beneficial community in non-crop and crop habitats Biol Control 58:103-112 doi:10.1016/j.biocontrol.2011.04.005

Almeida-Cortez JS, Shipley B, Arnason JT (1999) Do plant species with high relative growth rates have poorer chemical defences? Funct Ecol 13:819-827 doi:10.1046/j.1365-2435.1999.00383.x

Almohamad R, Verheggen FJ, Francis F, Haubruge E (2007) Predatory hoverflies select their oviposition site according to aphid host plant and aphid species Entomol Exp Appl 125:13-21 doi:10.1111/j.15707458.2007.00596.x

Alyokhin A et al. (2015) The Red Queen in a potato field: integrated pest management versus chemical dependency in Colorado potato beetle control Pest Manage Sci 71:343-356 doi:10.1002/ps.3826

Amaral D, Venzon M, dos Santos HH, Sujii ER, Schmidt JM, Harwood JD (2016) Non-crop plant communities conserve spider populations in chili pepper agroecosystems Biol Control 103:69-77 doi:10.1016/j.biocontrol.2016.07.007

Amarasekare P (2007) Trade-offs, temporal variation, and species coexistence in communities with intraguild predation Ecology 88:2720-2728 doi:10.1890/06-1515.1

Anderson A, Carnus T, Helden AJ, Sheridan H, Purvis G (2013) The influence of conservation field margins in intensively managed grazing land on communities of five arthropod trophic groups Insect Conservation and Diversity 6:201-211 doi:10.1111/j.1752-4598.2012.00203.x

Andow DA (1991) Vegetational diversity and arthropod population response Annu Rev Entomol 36:561-586 doi:10.1146/annurev.ento.36.1.561

Andrade TO, Outreman Y, Krespi L, Plantegenest M, Vialatte A, Gauffre B, van Baaren J (2015) Spatiotemporal variations in aphid-parasitoid relative abundance patterns and food webs in agricultural ecosystems Ecosphere 6:14 doi:10.1890/es15-00010.1

Aquilino KM, Cardinale BJ, Ives AR (2005) Reciprocal effects of host plant and natural enemy diversity on herbivore suppression: an empirical study of a model tritrophic system Oikos 108:275-282 doi:10.1111/j.0030-1299.2005.13418.x

Araj SE, Wratten S, Lister A, Buckley H (2008) Floral diversity, parasitoids and hyperparasitoids - A laboratory approach Basic and Applied Ecology 9:588-597 doi:10.1016/j.baae.2007.08.001

Arnold SEJ, Le Comber SC, Chittka L (2009) Flower color phenology in European grassland and woodland habitats, through the eyes of pollinators Isr J Plant Sci 57:211-230 doi:10.1560/IJPS.57.3.211 
Badenes-Perez FR, Marquez BP, Petitpierre E (2017) Can flowering Barbarea spp. (Brassicaceae) be used simultaneously as a trap crop and in conservation biological control? J Pest Sci 90:623-633 doi:10.1007/s10340-016-0815-y

Badenes-Perez FR, Reichelt M, Gershenzon J, Heckel DG (2014) Using plant chemistry and insect preference to study the potential of Barbarea (Brassicaceae) as a dead-end trap crop for diamondback moth (Lepidoptera: Plutellidae) Phytochemistry 98:137-144 doi:10.1016/j.phytochem.2013.11.009

Baggen LR, Gurr GM, Meats A (1999) Flowers in tri-trophic systems: mechanisms allowing selective exploitation by insect natural enemies for conservation biological control Entomol Exp Appl 91:155-161 doi:10.1046/j.1570-7458.1999.00478.x

Baker HG, Baker I (1983) Floral nectar sugar constituents in relation to pollinator type Handbook of experimental pollination biology:117-141

Ball SL, Woodcock BA, Potts SG, Heard MS (2015) Size matters: Body size determines functional responses of ground beetle interactions Basic and Applied Ecology 16:621-628 doi:10.1016/j.baae.2015.06.001

Ballhorn DJ, Godschalx AL, Smart SM, Kautz S, Schadler M (2014) Chemical defense lowers plant competitiveness Oecologia 176:811-824 doi:10.1007/s00442-014-3036-1

Balmer $\mathrm{O}$ et al. (2014a) Wildflower companion plants increase pest parasitation and yield in cabbage fields: experimental demonstration and call for caution Biol Control 76:19-27 doi:10.1016/j.biocontrol.2014.04.008

Balmer O, Pfiffner L, Schied J, Willareth M, Leimgruber A, Luka H, Traugott M (2014b) Noncrop flowering plants restore top-down herbivore control in agricultural fields Ecology and Evolution 3:2634-2646 doi:10.1002/ece3.658

Balzan M, Bocci G, Moonen A-C (2014) Augmenting flower trait diversity in wildflower strips to optimise the conservation of arthropod functional groups for multiple agroecosystem services J Insect Conserv 18:713728 doi:10.1007/s10841-014-9680-2

Balzan MV, Bocci G, Moonen AC (2016a) Landscape complexity and field margin vegetation diversity enhance natural enemies and reduce herbivory by Lepidoptera pests on tomato crop Biocontrol 61:141-154 doi:10.1007/s10526-015-9711-2

Balzan MV, Bocci G, Moonen AC (2016b) Utilisation of plant functional diversity in wildflower strips for the delivery of multiple agroecosystem services Entomol Exp Appl 158:304-319 doi:10.1111/eea.12403

Balzan MV, Moonen AC (2014) Field margin vegetation enhances biological control and crop damage suppression from multiple pests in organic tomato fields Entomol Exp Appl 150:45-65 doi:10.1111/eea.12142

Banks JE, Gagic V (2016) Aphid parasitoids respond to vegetation heterogeneity but not to fragmentation scale: an experimental field study Basic and Applied Ecology 17:438-446 doi:10.1016/j.baae.2016.01.007

Barari H, Cook SM, Clark SJ, Williams IH (2005) Effect of a turnip rape (Brassica rapa) trap crop on stem-mining pests and their parasitoids in winter oilseed rape (Brassica napus) Biocontrol 50:69-86 doi:10.1007/s10526004-0895-0

Bartomeus I, Gagic V, Bommarco R (sous presse) Pollinators, pests and soil properties interactively shape oilseed rape yield. doi:10.1101/010181

Bartomeus I, Gravel D, Tylianakis JM, Aizen MA, Dickie IA, Bernard-Verdier M (2016) A common framework for identifying linkage rules across different types of interactions Funct Ecol 30:1894-1903 doi:10.1111/13652435.12666

Beach JP, Williams L, Hendrix DL, Price LD (2003) Different food sources affect the gustatory response of Anaphes iole, an egg parasitoid of Lygus spp J Chem Ecol 29:1203-1222 doi:10.1023/a:1023837808291

Begg GS et al. (2017) A functional overview of conservation biological control Crop Prot 97:145-158 doi:http://dx.doi.org/10.1016/j.cropro.2016.11.008

Begum M, Gurr GM, Wratten SD, Nicol HI (2004) Flower color affects tri-trophic-level biocontrol interactions Biol Control 30:584-590 doi:10.1016/j.biocontrol.2004.03.005

Bell JR, King RA, Bohan DA, Symondson WOC (2010) Spatial co-occurrence networks predict the feeding histories of polyphagous arthropod predators at field scales Ecography 33:64-72 doi:10.1111/j.16000587.2009.06046.x

Belz E, Kölliker M, Balmer O (2013) Olfactory attractiveness of flowering plants to the parasitoid Microplitis mediator: potential implications for biological control Biocontrol 58:163-173 doi:10.1007/s10526-0129472-0

Berger J, Jönsson M, Hedlund K, Anderson P (2015) Niche separation of pollen beetle parasitoids Frontiers in Ecology and Evolution 3 doi:10.3389/fevo.2015.00045

Bertolaccini I, Núñez-Pérez E, Tizado EJ (2008) Effect of wild flowers on oviposition of Hippodamia variegata (Coleoptera: Coccinellidae) in the laboratory J Econ Entomol 101:1792-1797 doi:10.1603/0022-0493101.6.1792

Bianchi F, Wackers FL (2008) Effects of flower attractiveness and nectar availability in field margins on biological control by parasitoids Biol Control 46:400-408 doi:10.1016/j.biocontrol.2008.04.010 
Bílá K, Moretti M, de Bello F, Dias ATC, Pezzatti GB, Van Oosten AR, Berg MP (2014) Disentangling community functional components in a litter-macrodetritivore model system reveals the predominance of the mass ratio hypothesis Ecology and Evolution 4:408-416

Birkhofer K, Diekotter T, Meub C, Stotzel K, Wolters V (2015) Optimizing arthropod predator conservation in permanent grasslands by considering diversity components beyond species richness Agr Ecosyst Environ 211:65-72 doi:10.1016/j.agee.2015.05.014

Birkhofer K, Gavish-Regev E, Endlweber K, Lubin YD, von Berg K, Wise DH, Scheu S (2008a) Cursorial spiders retard initial aphid population growth at low densities in winter wheat Bull Entomol Res 98:249-255 doi:10.1017/s0007485308006019

Birkhofer K et al. (2017) Land-use type and intensity differentially filter traits in above- and below-ground arthropod communities J Anim Ecol 86:511-520 doi:10.1111/1365-2656.12641

Birkhofer K, Wise DH, Scheu S (2008b) Subsidy from the detrital food web, but not microhabitat complexity, affects the role of generalist predators in an aboveground herbivore food web Oikos 117:494-500 doi:10.1111/j.0030-1299.2008.16361.x

Bischoff A et al. (2016) Effects of spontaneous field margin vegetation and surrounding landscape on Brassica oleracea crop herbivory Agr Ecosyst Environ 223:135-143 doi:http://dx.doi.org/10.1016/j.agee.2016.02.029

Bitsch J, Leclercq J (1993) Hyménoptères Sphecidae d'Europe Occidentale, volume I. Faune de France 79. Fédération Française des Sociétés de Sciences Naturelles, Paris, France,

Björkman M, Hambäck PA, Hopkins RJ, Rämert B (2010) Evaluating the enemies hypothesis in a clover-cabbage intercrop: effects of generalist and specialist natural enemies on the turnip root fly (Delia floralis) Agric For Entomol 12:123-132 doi:10.1111/j.1461-9563.2009.00452.x

Blaauw BR, Isaacs R (2014a) Flower plantings increase wild bee abundance and the pollination services provided to a pollination-dependent crop J Appl Ecol sous presse:n/a-n/a doi:10.1111/1365-2664.12257

Blaauw BR, Isaacs R (2014b) Larger wildflower plantings increase natural enemy density, diversity, and biological control of sentinel prey, without increasing herbivore density Ecol Entomol 37:386-394 doi:10.1111/j.13652311.2012.01376.x

Blitzer EJ, Dormann CF, Holzschuh A, Klein AM, Rand TA, Tscharntke T (2012) Spillover of functionally important organisms between managed and natural habitats Agr Ecosyst Environ 146:34-43 doi:10.1016/j.agee.2011.09.005

Bohan DA et al. (2013) Networking agroecology: integrating the diversity of agroecosystem interactions. In: Ecological Networks in an Agricultural World, vol 49. Advances in Ecological Research. Elsevier Academic Press Inc, San Diego, pp 1-67. doi:10.1016/b978-0-12-420002-9.00001-9

Botías C, David A, Horwood J, Abdul-Sada A, Nicholls E, Hill E, Goulson D (2015) Neonicotinoid residues in wildflowers, a potential route of chronic exposure for bees Environ Sci Technol 49:12731-12740 doi:10.1021/acs.est.5b03459

Boukal DS (2014) Trait- and size-based descriptions of trophic links in freshwater food webs: current status and perspectives J Limnol 73:171-185 doi:10.4081/jlimnol.2014.826

Brittain C, Bommarco R, Vighi M, Settele J, Potts SG (2010) Organic farming in isolated landscapes does not benefit flower-visiting insects and pollination Biol Conserv 143:1860-1867 doi:10.1016/j.biocon.2010.04.029

Brooks DR, Storkey J, Clark SJ, Firbank LG, Petit S, Woiwod IP (2012) Trophic links between functional groups of arable plants and beetles are stable at a national scale J Anim Ecol 81:4-13 doi:10.1111/j.13652656.2011.01897.x

Brose U (2003) Bottom-up control of carabid beetle communities in early successional wetlands: mediated by vegetation structure or plant diversity? Oecologia 135:407-413 doi:10.1007/s00442-003-1222-7

Brousseau P-M, Gravel D, Handa IT Trait matching and phylogeny as predictors of predator-prey interactions involving ground beetles Funct Ecol:n/a-n/a doi:10.1111/1365-2435.12943

Bruno JF, Cardinale BJ (2008) Cascading effects of predator richness Front Ecol Environ 6:539-546 doi:10.1890/070136

Bucher R, Menzel F, Entling MH (2015) Risk of spider predation alters food web structure and reduces local herbivory in the field Oecologia 178:571-577 doi:10.1007/s00442-015-3226-5

Büchs W, Nuss H (2000) First steps to assess the importance of epigaeic active polyphagous predators on oilseed rape insect pests with soil pupating larvae. Paper presented at the Bulletin OILB/SROP, Prague, Czech Republic,

Bukovinszky T, van Veen FJF, Jongema Y, Dicke M (2008) Direct and indirect effects of resource quality on food web structure Science 319:804-807 doi:10.1126/science.1148310

Bürki H-M, Hausammann A (1992) Überwinterung von Arthropoden im Boden und an Ackerkraütern künstlich angelegter Ackerkrautstreifen Agrarökologie 7:1-158

Button L, Elle E (2014) Wild bumble bees reduce pollination deficits in a crop mostly visited by managed honey bees Agr Ecosyst Environ 197:255-263 doi:10.1016/j.agee.2014.08.004 
Byrnes JE, Stachowicz JJ (2009) The consequences of consumer diversity loss: different answers from different experimental designs Ecology 90:2879-2888 doi:10.1890/08-1073.1

Caballero-Lopez B et al. (2012) Weeds, aphids, and specialist parasitoids and predators benefit differently from organic and conventional cropping of winter cereals J Pest Sci 85:81-88 doi:10.1007/s 10340-011-0409-7

Cadotte MW, Cardinale BJ, Oakley TH (2008) Evolutionary history and the effect of biodiversity on plant productivity Proc Natl Acad Sci U S A 105:17012-17017 doi:10.1073/pnas.0805962105

Campbell AJ, Biesmeijer JC, Varma V, Wäckers FL (2012) Realising multiple ecosystem services based on the response of three beneficial insect groups to floral traits and trait diversity Basic and Applied Ecology 13:363-370 doi:10.1016/j.baae.2012.04.003

Cardinale BJ, Weis JJ, Forbes AE, Tilmon KJ, Ives AR (2006) Biodiversity as both a cause and consequence of resource availability: a study of reciprocal causality in a predator-prey system J Anim Ecol 75:497-505 doi:10.1111/j.1365-2656.2006.01070.x

Carmona CP, de Bello F, Mason NWH, Leps J (2016) Traits without borders: integrating functional diversity across scales Trends in Ecology \& Evolution 31:382-394 doi:10.1016/j.tree.2016.02.003

Carmona D, Lajeunesse MJ, Johnson MTJ (2011) Plant traits that predict resistance to herbivores Funct Ecol 25:358367 doi:10.1111/j.1365-2435.2010.01794.x

Caro G, Marrec R, Gauffre B, Roncoroni M, Augiron S, Bretagnolle V (2016) Multi-scale effects of agrienvironment schemes on carabid beetles in intensive farmland Agr Ecosyst Environ 229:48-56 doi:10.1016/j.agee.2016.05.009

Carreck NL, Williams IH (1997) Observations on two commercial flower mixtures as food sources for beneficial insects in the UK J Agr Sci 128:397-403 doi:10.1017/s0021859697004279

Carrié RJG, George DR, Wäckers FL (2012) Selection of floral resources to optimise conservation of agriculturallyfunctional insect groups J Insect Conserv 16:635-640 doi:10.1007/s10841-012-9508-x

Carval D, Resmond R, Achard R, Tixier P (2016) Cover cropping reduces the abundance of the banana weevil Cosmopolites sordidus but does not reduce its damage to the banana plants Biol Control 99:14-18 doi:10.1016/j.biocontrol.2016.04.004

Carvalheiro LG et al. (2014) The potential for indirect effects between co-flowering plants via shared pollinators depends on resource abundance, accessibility and relatedness Ecology Letters 17:1389-1399 doi:10.1111/ele. 12342

Carvell C, Westrich P, Meek WR, Pywell RF, Nowakowski M (2006) Assessing the value of annual and perennial forage mixtures for bumblebees by direct observation and pollen analysis Apidologie 37:326-340 doi:10.1051/apido:2006002

Chailleux A, Mohl E, Teixeira Alves M, Messelink G, Desneux N (2014) Natural enemy-mediated indirect interactions among prey species: potential for enhancing biocontrol services in agroecosystems Pest Manage Sci 70:1769-1779 doi:10.1002/ps.3916

Chamberlain SA, Kilpatrick JR, Holland JN (2010) Do extrafloral nectar resources, species abundances, and body sizes contribute to the structure of ant-plant mutualistic networks? Oecologia 164:741-750 doi:10.1007/s00442-010-1673-6

Chang GC, Snyder WE (2004) The relationship between predator density, community composition, and field predation of Colorado potato beetle eggs Biol Control 31:453-461 doi:http://dx.doi.org/10.1016/j.biocontrol.2004.07.009

Chaplin-Kramer R, Kremen C (2012) Pest control experiments show benefits of complexity at landscape and local scales Ecological Applications 22:1936-1948

Chen XQ, Chen YC, Wu LB, Peng Y, Chen JA, Liu FX (2010) A survey of nectar feeding by spiders in three different habitats Bull Insectol 63:203-208

Cocco N, Glendinning JI (2012) Not all sugars are created equal: some mask aversive tastes better than others in an herbivorous insect J Exp Biol 215:1412-1421 doi:10.1242/jeb.059832

Cole LJ et al. (2002) Relationships between agricultural management and ecological groups of ground beetles (Coleoptera : Carabidae) on Scottish farmland Agr Ecosyst Environ 93:323-336 doi:10.1016/s01678809(01)00333-4

Coleman D, Fu SL, Hendrix P, Crossley D (2002) Soil foodwebs in agroecosystems: impacts of herbivory and tillage management European Journal of Soil Biology 38:21-28 doi:10.1016/s1164-5563(01)01118-9

Coll M, Guershon M (2002) Omnivory in terrestrial arthropods: Mixing plant and prey diets Annu Rev Entomol 47:267-297 doi:10.1146/annurev.ento.47.091201.145209

Collins KL, Boatman ND, Wilcox A, Holland JM, Chaney K (2002) Influence of beetle banks on cereal, aphid predation in winter wheat Agr Ecosyst Environ 93:337-350 doi:10.1016/s0167-8809(01)00340-1

Cook SM, Smart LE, Martin JL, Murray DA, Watts NP, Williams IH (2006) Exploitation of host plant preferences in pest management strategies for oilseed rape (Brassica napus) Entomol Exp Appl 119:221-229 doi:10.1111/j.1570-7458.2006.00419.x

Corbett A, Rosenheim JA (1996) Quantifying movement of a minute parasitoid, Anagrus epos (Hymenoptera: 
Mymaridae), using fluorescent dust marking and recapture Biol Control 6:35-44 doi:10.1006/bcon.1996.0005

Corcket E, Giffard B, Sforza RFH (2017) Food Webs and Multiple Biotic Interactions in Plant-Herbivore Models. In: Sauvion N, Thiery D, Calatayud PA (eds) Insect-Plant Interactions in a Crop Protection Perspective, vol 81. Advances in Botanical Research. pp 111-137. doi:10.1016/bs.abr.2016.10.002

Costanzo A, Barberi P (2014) Functional agrobiodiversity and agroecosystem services in sustainable wheat production. A review Agronomy for Sustainable Development 34:327-348 doi:10.1007/s13593-013-0178-1

Coudrain V et al. (2016) Temporal differentiation of soil communities in response to arable crop management strategies Agr Ecosyst Environ 225:12-21 doi:10.1016/j.agee.2016.03.029

Coux C, Rader R, Bartomeus I, Tylianakis JM (2016) Linking species functional roles to their network roles Ecology Letters 19:762-770 doi:10.1111/ele.12612

Crea C, Ali RA, Rader R (2016) A new model for ecological networks using species-level traits Methods in Ecology and Evolution 7:232-241 doi:10.1111/2041-210x.12471

Cronin JP, Tonsor SJ, Carson WP (2010) A simultaneous test of trophic interaction models: which vegetation characteristic explains herbivore control over plant community mass? Ecology Letters 13:202-212 doi:10.1111/j.1461-0248.2009.01420.x

Cronin JT, Reeve JD (2005) Host-parasitoid spatial ecology: a plea for a landscape-level synthesis Proceedings of the Royal Society B-Biological Sciences 272:2225-2235 doi:10.1098/rspb.2005.3286

Crowder DW, Jabbour R (2014) Relationships between biodiversity and biological control in agroecosystems: Current status and future challenges Biol Control 75:8-17 doi:10.1016/j.biocontrol.2013.10.010

Crowder DW, Northfield TD, Strand MR, Snyder WE (2010) Organic agriculture promotes evenness and natural pest control Nature 466:109-U123 doi:10.1038/nature09183

Dainese M, Riedinger V, Holzschuh A, Kleijn D, Scheper J, Steffan-Dewenter I Managing trap-nesting bees as crop pollinators: Spatiotemporal effects of floral resources and antagonists J Appl Ecol:n/a-n/a doi:10.1111/1365-2664.12930

Dainese M, Schneider G, Krauss J, Steffan-Dewenter I (2017) Complementarity among natural enemies enhances pest suppression Scientific Reports 7:8 doi:10.1038/s41598-017-08316-Z

Damien M, Le Lann C, Desneux N, Alford L, Al Hassan D, Georges R, Van Baaren J (2017) Flowering cover crops in winter increase pest control but not trophic link diversity Agr Ecosyst Environ 247:418-425 doi:https://doi.org/10.1016/j.agee.2017.07.015

Damour G, Navas ML, Garnier É (2017) A revised trait-based framework for agroecosystems including decision rules J Appl Ecol sous presse:n/a-n/a doi:10.1111/1365-2664.12986

Dassou AG, Tixier P (2016) Response of pest control by generalist predators to local-scale plant diversity: a metaanalysis Ecology and Evolution 6:1143-1153 doi:10.1002/ece3.1917

Davey JS et al. (2013) Intraguild predation in winter wheat: prey choice by a common epigeal carabid consuming spiders J Appl Ecol 50:271-279 doi:10.1111/1365-2664.12008

Day RL, Hickman JM, Sprague RI, Wratten SD (2015) Predatory hoverflies increase oviposition in response to colour stimuli offering no reward: Implications for biological control Basic and Applied Ecology 16:544552 doi:10.1016/j.baae.2015.05.004

de Rijk M, Wang QJ, Papagiannaki E, Dicke M, Poelman EH (2016) Herbivore species identity rather than diversity of the non-host community determines foraging behaviour of the parasitoid wasp Cotesia glomerata Entomol Exp Appl 161:20-30 doi:10.1111/eea.12493

Delettre YR, Morvan N, Tréhen P, Grootaert P (1998) Local biodiversity and multi-habitat use in empidoid flies (Insecta: Diptera, Empidoidea) Biodivers Conserv 7:9-25

Denoth M, Frid L, Myers JH (2002) Multiple agents in biological control: improving the odds? Biol Control 24:2030 doi:10.1016/s1049-9644(02)00002-6

Denys C, Tscharntke T (2002) Plant-insect communities and predator-prey ratios in field margin strips, adjacent crop fields, and fallows Ecologia 130:315-324 doi:10.1007/s004420100796

Deraison H, Badenhausser I, Loeuille N, Scherber C, Gross N (2015) Functional trait diversity across trophic levels determines herbivore impact on plant community biomass Ecology Letters 18:1346-1355 doi:10.1111/ele.12529

DeWitt TJ, Langerhans RB (2003) Multiple prey traits, multiple predators: keys to understanding complex community dynamics J Sea Res 49:143-155 doi:10.1016/s1385-1101(02)00220-4

Dias ATC, Berg MP, de Bello F, Van Oosten AR, Bílá K, Moretti M (2013) An experimental framework to identify community functional components driving ecosystem processes and services delivery J Ecol 101:29-37 doi:10.1111/1365-2745.12024

Dib H, Libourel G, Warlop F (2012) Entomological and functional role of floral strips in an organic apple orchard: Hymenopteran parasitoids as a case study J Insect Conserv 16:315-318 doi:10.1007/s10841-012-9471-6

Diehl E, Mader VL, Wolters V, Birkhofer K (2013a) Management intensity and vegetation complexity affect webbuilding spiders and their prey Oecologia 173:579-589 doi:10.1007/s00442-013-2634-7 
Diehl E, Sereda E, Wolters V, Birkhofer K (2013b) Effects of predator specialization, host plant and climate on biological control of aphids by natural enemies: a meta-analysis J Appl Ecol 50:262-270 doi:10.1111/13652664.12032

Diehl E, Wolters V, Birkhofer K (2012) Arable weeds in organically managed wheat fields foster carabid beetles by resource- and structure-mediated effects Arthropod-Plant Interactions 6:75-82 doi:10.1007/s11829-0119153-4

Ditner N, Balmer O, Beck J, Blick T, Nagel P, Luka H (2013) Effects of experimentally planting non-crop flowers into cabbage fields on the abundance and diversity of predators Biodivers Conserv 22:1049-1061 doi:10.1007/s10531-013-0469-5

Douglas MR, Rohr JR, Tooker JF (2015) Neonicotinoid insecticide travels through a soil food chain, disrupting biological control of non-target pests and decreasing soya bean yield J Appl Ecol:n/a-n/a doi:10.1111/13652664.12372

Drieu R, Rusch A (2017) Conserving species-rich predator assemblages strengthens natural pest control in a climate warming context Agric For Entomol 19:52-59 doi:10.1111/afe.12180

Du YJ, Poppy GM, Powell W (1996) Relative importance of semiochemicals from first and second trophic levels in host foraging behavior of Aphidius ervi J Chem Ecol 22:1591-1605 doi:10.1007/bf02272400

Duffield SJ, Jepson PC, Wratten SD, Sotherton NW (1996) Spatial changes in invertebrate predation rate in winter wheat following treatment with dimethoate Entomol Exp Appl 78:9-17

Duyck PF, Lavigne A, Vinatier F, Achard R, Okolle JN, Tixier P (2011) Addition of a new resource in agroecosystems: do cover crops alter the trophic positions of generalist predators? Basic and Applied Ecology 12:47-55 doi:10.1016/j.baae.2010.11.009

Ernoult A, Vialatte A, Butet A, Michel N, Rantier Y, Jambon O, Burel F (2013) Grassy strips in their landscape context, their role as new habitat for biodiversity Agr Ecosyst Environ 166:15-27 doi:10.1016/j.agee.2012.07.004

Eubanks MD, Finke DL (2014) Interaction webs in agroecosystems: beyond who eats whom Current Opinion in Insect Science 2:1-6 doi:10.1016/j.cois.2014.06.005

Evans DM et al. (2015) The cascading impacts of livestock grazing in upland ecosystems: a 10-year experiment Ecosphere 6 doi:10.1890/es14-00316.1

Evans EW (2016) Biodiversity, ecosystem functioning, and classical biological control Appl Entomol Zool 51:173184 doi:10.1007/s13355-016-0401-z

Fahey JW, Zalcmann AT, Talalay P (2001) The chemical diversity and distribution of glucosinolates and isothiocyanates among plants Phytochemistry 56:5-51 doi:10.1016/s0031-9422(00)00316-2

Feltham H, Park K, Minderman J, Goulson D (2015) Experimental evidence that wildflower strips increase pollinator visits to crops Ecology and Evolution 5:3523-3530 doi:10.1002/ece3.1444

Feng Y, Kravchuk O, Sandhu H, Wratten SD, Keller MA (2017) The activities of generalist parasitoids can be segregated between crop and adjacent non-crop habitats J Pest Sci 90:275-286 doi:10.1007/s10340-0160775-2

Ferguson AW, Barari H, Warner DJ, Campbell JM, Smith ET, Watts NP, Williams IH (2006) Distributions and interactions of the stem miners Psylliodes chrysocephala and Ceutorhynchus pallidactylus and their parasitoids in a crop of winter oilseed rape (Brassica napus) Entomol Exp Appl 119:81-92 doi:10.1111/j.1570-7458.2006.00404.x

Ferguson AW, Klukowski Z, Walczak B, Clark SJ, Mugglestone MA, Perry JN, Williams IH (2003) Spatial distribution of pest insects in oilseed rape: implications for integrated pest management Agr Ecosyst Environ 95:509-521 doi:10.1016/s0167-8809(02)00200-1

Fiedler AK, Landis DA (2007) Plant characteristics associated with natural enemy abundance at Michigan native plants Environ Entomol 36:878-886 doi:10.1603/0046-225x(2007)36[878:pcawne]2.0.co;2

Finke DL, Denno RF (2006) Spatial refuge from intraguild predation: implications for prey suppression and trophic cascades Oecologia 149:265-275 doi:10.1007/s00442-006-0443-y

Finke DL, Snyder WE (2010) Conserving the benefits of predator biodiversity Biol Conserv 143:2260-2269 doi:10.1016/j.biocon.2010.03.022

Fischbein D, Jofré N, Corley JC (2016) A comparative analysis of host feeding and life-history traits in parasitoid wasps Entomol Exp Appl 159:172-180 doi:10.1111/eea.12422

Frank SD, Wratten SD, Sandhu HS, Shrewsbury PM (2007) Video analysis to determine how habitat strata affects predator diversity and predation of Epiphyas postvittana (Lepidoptera : Tortricidae) in a vineyard Biol Control 41:230-236 doi:10.1016/j.biocontrol.2007.01.012

Frank T (1998) Slug damage and numbers of the slug pests, Arion lusitanicus and Deroceras reticulatum, in oilseed rape grown beside sown wildflower strips Agr Ecosyst Environ 67:67-78 doi:10.1016/s01678809(97)00108-4

Freeman Long R, Corbett Z, Lamb C, Reberg-Horton C, Chandler J, Stimmann M (1998) Beneficial insects move from flowering plants to nearby crops Calif Agric 52:23-26 
Frei G, Manhart C (1992) Nützlinge and Schädlinge an künstlich angelegten Acherkrautstreifen in Getreidefeldern. Agrarökologie, bd.4.

Freier B, Triltsch H, Möwes M, Moll E (2007) The potential of predators in natural control of aphids in wheat: results of a ten-year field study in two German landscapes Biocontrol 52:775-788 doi:10.1007/s10526-0079081-5

Frenette-Dussault C, Shipley B, Hingrat Y (2013) Linking plant and insect traits to understand multitrophic community structure in arid steppes Funct Ecol 27:786-792 doi:10.1111/1365-2435.12075

Furlong MJ, Zalucki MP (2010) Exploiting predators for pest management: the need for sound ecological assessment Entomol Exp Appl 135:225-236 doi:10.1111/j.1570-7458.2010.00988.x

Fusser MS, Pfister SC, Entling MH, Schirmel J (2017) Effects of field margin type and landscape composition on predatory carabids and slugs in wheat fields Agr Ecosyst Environ 247:182-188 doi:http://dx.doi.org/10.1016/j.agee.2017.06.030

Gagic V et al. (2015) Functional identity and diversity of animals predict ecosystem functioning better than speciesbased indices Proc R Soc B 282:sous presse doi:10.1098/rspb.2014.2620

Gagic V, Hänke S, Thies C, Scherber C, Tomanović Ž, Tscharntke T (2012) Agricultural intensification and cereal aphid-parasitoid-hyperparasitoid food webs: network complexity, temporal variability and parasitism rates Ecologia 170:1099-1109 doi:10.1007/s00442-012-2366-0

Gagic V, Petrovic-Obradovic O, Frund J, Kavallieratos NG, Athanassiou CG, Stary P, Tomanovic Z (2016a) The Effects of Aphid Traits on Parasitoid Host Use and Specialist Advantage Plos One 11 doi:10.1371/journal.pone.0157674

Gagic V, Riggi LGA, Ekbom B, Malsher G, Rusch A, Bommarco R (2016b) Interactive effects of pests increase seed yield Ecology and Evolution 6:2149-2157 doi:10.1002/ece3.2003

Gagic V, Tscharntke T, Dormann CF, Gruber B, Wilstermann A, Thies C (2011) Food web structure and biocontrol in a four-trophic level system across a landscape complexity gradient Proceedings of the Royal Society BBiological Sciences 278:2946-2953 doi:10.1098/rspb.2010.2645

Gaines HR, Gratton C (2010) Seed predation increases with ground beetle diversity in a Wisconsin (USA) potato agroecosystem Agr Ecosyst Environ 137:329-336 doi:10.1016/j.agee.2010.03.003

Gamfeldt L, Roger F (2017) Revisiting the biodiversity-ecosystem multifunctionality relationship Nature Ecology \& Evolution 1:s41559-41017 doi:10.1038/s41559-017-0168

Garibaldi LA et al. (2015) Trait matching of flower visitors and crops predicts fruit set better than trait diversity $\mathrm{J}$ Appl Ecol 52:1436-1444 doi:10.1111/1365-2664.12530

Garnier É, Navas M-L, Grigulis K (2016) Plant functional diversity. Oxford University Press, United Kingdom,

Garratt MPD, Senapathi D, Coston DJ, Mortimer SR, Potts SG (2017) The benefits of hedgerows for pollinators and natural enemies depends on hedge quality and landscape context Agr Ecosyst Environ 247:363-370 doi:10.1016/j.agee.2017.06.048

Geiger F, Wäckers F, Bianchi F (2009) Hibernation of predatory arthropods in semi-natural habitats Biocontrol 54:529-535 doi:10.1007/s10526-008-9206-5

Géneau CE, Wäckers FL, Luka H, Daniel C, Balmer O (2012) Selective flowers to enhance biological control of cabbage pests by parasitoids Basic and Applied Ecology 13:85-93 doi:10.1016/j.baae.2011.10.005

Gilabert A et al. (2017) Influence of the surrounding landscape on the colonization rate of cereal aphids and phytovirus transmission in autumn J Pest Sci 90:447-457 doi:10.1007/s10340-016-0790-3

Gillespie M, Wratten S, Sedcole R, Colfer R (2011) Manipulating floral resources dispersion for hoverflies (Diptera: Syrphidae) in a California lettuce agro-ecosystem Biol Control 59:215-220 doi:10.1016/j.biocontrol.2011.07.010

Gillespie MAK, Gurr GM, Wratten SD (2016) Beyond nectar provision: the other resource requirements of parasitoid biological control agents Entomol Exp Appl 159:207-221 doi:10.1111/eea.12424

Gontijo LM, Beers EH, Snyder WE (2015) Complementary suppression of aphids by predators and parasitoids Biol Control 90:83-91 doi:10.1016/j.biocontrol.2015.06.002

Gonzalez E, Salvo A, Valladares G (2015) Sharing enemies: evidence of forest contribution to natural enemy communities in crops, at different spatial scales Insect Conservation and Diversity 8:359-366 doi:10.1111/icad.12117

Grass I, Albrecht J, Jauker F, Diekötter T, Warzecha D, Wolters V, Farwig N (2016) Much more than bees Wildflower plantings support highly diverse flower-visitor communities from complex to structurally simple agricultural landscapes Agr Ecosyst Environ 225:45-53 doi:10.1016/j.agee.2016.04.001

Grass I, Lehmann K, Thies C, Tscharntke T (2017) Insectivorous birds disrupt biological control of cereal aphids Ecology:n/a-n/a doi:10.1002/ecy.1814

Gravel D, Albouy C, Thuiller W (2016) The meaning of functional trait composition of food webs for ecosystem functioning Philosophical Transactions of the Royal Society B-Biological Sciences 371 doi:10.1098/rstb.2015.0268

Gravel D, Poisot T, Albouy C, Velez L, Mouillot D (2013) Inferring food web structure from predator-prey body 
size relationships Methods in Ecology and Evolution 4:1083-1090 doi:10.1111/2041-210x.12103

Griffiths GJK, Holland JM, Bailey A, Thomas MB (2008) Efficacy and economics of shelter habitats for conservation biological control Biol Control 45:200-209 doi:10.1016/j.biocontrol.2007.09.002

Griffiths GJK, Winder L, Holland JM, Thomas CFG, Williams E (2007) The representation and functional composition of carabid and staphylinid beetles in different field boundary types at a farm-scale Biol Conserv 135:145-152 doi:10.1016/j.biocon.2006.09.016

Grime JP (1998) Benefits of plant diversity to ecosystems: immediate, filter and founder effects J Ecol 86:902-910

Guerrieri E, Poppy GM, Powell W, Rao R, Pennacchio F (2002) Plant-to-plant communication mediating in-flight orientation of Aphidius ervi J Chem Ecol 28:1703-1715 doi:10.1023/a:1020553531658

Gunton RM (2011) Integrating associational resistance into arable weed management Agr Ecosyst Environ 142:129136 doi:10.1016/j.agee.2011.05.022

Gurr GM et al. (2016) Multi-country evidence that crop diversification promotes ecological intensification of agriculture Nature Plants 2:1:3

Gurr GM, Wratten SD, Landis DA, You MS (2017) Habitat management to suppress pest populations: progress and prospects. In: Berenbaum MR (ed) Annual Review of Entomology, Vol 62, vol 62. Annual Review of Entomology. Annual Reviews, Palo Alto, pp 91-109. doi:10.1146/annurev-ento-031616-035050

Haaland C, Naisbit RE, Bersier LF (2011) Sown wildflower strips for insect conservation: a review Insect Conservation and Diversity 4:60-80 doi:10.1111/j.1752-4598.2010.00098.x

Haenke S, Scheid B, Schaefer M, Tscharntke T, Thies C (2009) Increasing syrphid fly diversity and density in sown flower strips within simple vs. complex landscapes J Appl Ecol 46:1106-1114 doi:10.1111/j.13652664.2009.01685.x

Hallem EA, Dahanukar A, Carlson JR (2006) Insect odor and taste receptors. In: Annual Review of Entomology, vol 51. Annual Review of Entomology. Annual Reviews, Palo Alto, pp 113-135. doi:10.1146/annurev.ento.51.051705.113646

Hallett RH, Bahlai CA, Xue YG, Schaafsma AW (2014) Incorporating natural enemy units into a dynamic action threshold for the soybean aphid, Aphis glycines ( Homoptera: Aphididae) Pest Manage Sci 70:879-888 doi:10.1002/ps.3674

Hamon N, Bardner R, Allenwilliams L, Lee JB (1990) Carabid populations in field beans and their effect on the population-dynamics of Sitona lineatus (L.) Ann Appl Biol 117:51-62 doi:10.1111/j.17447348.1990.tb04194.x

Hansen JP, Sagerman J, Wikstrom SA (2010) Effects of plant morphology on small-scale distribution of invertebrates Mar Biol 157:2143-2155 doi:10.1007/s00227-010-1479-4

Hanson HI, Palmu E, Birkhofer K, Smith HG, Hedlund K (2016) Agricultural land use determines the trait composition of ground beetle communities Plos One 11:13 doi:10.1371/journal.pone.0146329

Hanson HI, Smith HG, Hedlund K (2015) Agricultural management reduces emergence of pollen beetle parasitoids Agr Ecosyst Environ 205:9-14 doi:10.1016/j.agee.2015.03.001

Harmon JP, Ives AR, Losey JE, Olson AC, Rauwald KS (2000) Colemegilla maculata (Coleoptera : Coccinellidae) predation on pea aphids promoted by proximity to dandelions Oecologia 125:543-548 doi: $10.1007 / \mathrm{s} 004420000476$

Harvey JA, Gols R (2011) Population-related variation in plant defense more strongly affects survival of an herbivore than Its solitary parasitoid wasp J Chem Ecol 37:1081-1090 doi:10.1007/s10886-011-0024-3

Harvey JA, Snaas H, Malcicka M, Visser B, Bezemer TM (2014) Small-scale spatial resource partitioning in a hyperparasitoid community Arthropod-Plant Interactions 8:393-401 doi:10.1007/s11829-014-9319-y

Harvey JA, van der Putten WH, Turin H, Wagenaar R, Bezemer TM (2008) Effects of changes in plant species richness and community traits on carabid assemblages and feeding guilds Agr Ecosyst Environ 127:100-106 doi:10.1016/j.agee.2008.03.006

Harwood JD et al. (2009) Invertebrate biodiversity affects predator fitness and hence potential to control pests in crops Biol Control 51:499-506 doi:10.1016/j.biocontrol.2009.09.007

Harwood JD, Sunderland KD, Symondson WOC (2005) Monoclonal antibodies reveal the potential of the tetragnathid spider Pachygnatha degeeri (Araneae : Tetragnathidae) as an aphid predator Bull Entomol Res 95:161-167

Hatt S et al. (2017) Do flower mixtures with high functional diversity enhance aphid predators in wildflower strips? Eur J Entomol 114:66-76 doi:10.14411/eje.2017.010

Hatt $\mathrm{S}$ et al. (2015) Do wildflower strips favor insect pest populations at field margins? Agriculture and agricultural science procedia 6:30-37

Hausammann A (1996a) The effects of weed strip-management on pests and beneficial arthropods in winter wheat fields Z Pflanzenk Pflanzens-J Plant Dis Prot 103:70-81

Hausammann A (1996b) Strip-management in rape crop: is winter rape endangered by negative impacts of sown weed strips? J Appl Entomol 120:505-512

Hawlena D, Hughes KM, Schmitz OJ (2011) Trophic trait plasticity in response to changes in resource availability 
and predation risk Funct Ecol 25:1223-1231 doi:10.1111/j.1365-2435.2011.01891.x

Hector A et al. (1999) Plant diversity and productivity experiments in European grasslands Science 286:1123-1127 doi:10.1126/science.286.5442.1123

Heil M (2008) Indirect defence via tritrophic interactions New Phytol 178:41-61 doi:10.1111/j.14698137.2007.02330.x

Heimpel GE, Jervis MA (2005) Does floral nectar improve biological control by parasitoids? In: Wäckers F, van Rijn P, Bruin J (eds) Plant-provided food and plant-carnivore mutualism. Cambridge University Press, Cambridge, UK, pp 267-304

Henry LM, Bannerman JA, Gillespie DR, Roitberg BD (2010) Predator identity and the nature and strength of food web interactions J Anim Ecol 79:1164-1171 doi:10.1111/j.1365-2656.2010.01723.x

Herrault PA et al. (2016) Combined effects of area, connectivity, history and structural heterogeneity of woodlands on the species richness of hoverflies (Diptera: Syrphidae) Landsc Ecol 31:877-893 doi:10.1007/s10980015-0304-3

Hicks DM et al. (2016) Food for pollinators: quantifying the nectar and pollen resources of urban flower meadows Plos One 11:37 doi:10.1371/journal.pone.0158117

Hillebrand H, Bennett DM, Cadotte MW (2008) Consequences of dominance: a review of evenness effects on local and regional ecosystem processes Ecology 89:1510-1520 doi:10.1890/07-1053.1

Hof AR, Bright PW (2010) The impact of grassy field margins on macro-invertebrate abundance in adjacent arable fields Agr Ecosyst Environ 139:280-283 doi:10.1016/j.agee.2010.08.014

Hogg BN, Bugg RL, Daane KM (2011) Attractiveness of common insectary and harvestable floral resources to beneficial insects Biol Control 56:76-84 doi:10.1016/j.biocontrol.2010.09.007

Holland JM, Bianchi FJJA, Entling MH, Moonen A-C, Smith BM, Jeanneret P (2016) Structure, function and management of semi-natural habitats for conservation biological control: a review of European studies Pest Manage Sci 72:1638-1651 doi:10.1002/ps.4318

Holland JM, Douma JC, Crowley L, James L, Kor L, Stevenson DRW, Smith BM (2017) Semi-natural habitats support biological control, pollination and soil conservation in Europe. A review Agronomy for Sustainable Development 37:23 doi:10.1007/s13593-017-0434-x

Holland JM, Oaten H, Moreby S, Birkett T, Simper J, Southway S, Smith BM (2012) Agri-environment scheme enhancing ecosystem services: A demonstration of improved biological control in cereal crops Agr Ecosyst Environ 155:147-152 doi:10.1016/j.agee.2012.04.014

Holland JM, Oaten H, Southway S, Moreby S (2008) The effectiveness of field margin enhancement for cereal aphid control by different natural enemy guilds Biol Control 47:71-76 doi:10.1016/j.biocontrol.2008.06.010

Hooks CRR, Johnson MW (2003) Impact of agricultural diversification on the insect community of cruciferous crops Crop Prot 22:223-238 doi:10.1016/s0261-2194(02)00172-2

Huang JH, Liu MQ, Chen FJ, Griffiths BS, Chen XY, Johnson SN, Hu F (2012) Crop resistance traits modify the effects of an aboveground herbivore, brown planthopper, on soil microbial biomass and nematode community via changes to plant performance Soil Biology \& Biochemistry 49:157-166 doi:10.1016/j.soilbio.2012.02.022

Ibanez S (2012) Optimizing size thresholds in a plant-pollinator interaction web: towards a mechanistic understanding of ecological networks Oecologia 170:233-242 doi:10.1007/s00442-012-2290-3

Ibanez S, Lavorel S, Puijalon S, Moretti M (2013) Herbivory mediated by coupling between biomechanical traits of plants and grasshoppers Funct Ecol 27:479-489 doi:10.1111/1365-2435.12058

Inclan DJ, Dainese M, Cerretti P, Paniccia D, Marini L (2016) Spillover of tachinids and hoverflies from different field margins Basic and Applied Ecology 17:33-42 doi:10.1016/j.baae.2015.08.005

Isaacs R, Tuell J, Fiedler A, Gardiner M, Landis D (2009) Maximizing arthropod-mediated ecosystem services in agricultural landscapes: the role of native plants Front Ecol Environ 7:196-203 doi:10.1890/080035

Isbell $\mathrm{F}$ et al. (2011) High plant diversity is needed to maintain ecosystem services Nature 477:199-U196 doi:10.1038/nature 10282

Iverson AL et al. (2014) Do polycultures promote win-wins or trade-offs in agricultural ecosystem services? A metaanalysis J Appl Ecol 51:1593-1602 doi:10.1111/1365-2664.12334

Jamont M, Crépellière S, Jaloux B (2013) Effect of extrafloral nectar provisioning on the performance of the adult parasitoid Diaeretiella rapae Biol Control 65:271-277 doi:10.1016/j.biocontrol.2013.01.010

Jansen JP, Chavalle S (2014) A study to assess the parasitism of insect pests in winter oilseed rape in Belgium: preliminary results IOBC/WPRS Bulletin 104:53-59

Jauker F, Bondarenko B, Becker HC, Steffan-Dewenter I (2012) Pollination efficiency of wild bees and hoverflies provided to oilseed rape Agric For Entomol 14:81-87 doi:10.1111/j.1461-9563.2011.00541.x

Jervis MA, Lee JC, Heimpel GE (2004) Use of behavioural and life-history studies to understand the effects of habitat manipulation. In: Gurr GM, Wratten SD, Altieri MA (eds) Ecological engineering for pest management. CSIRO, Wallingford, UK, pp 65-100

Jonsson $\mathrm{M}$ et al. (2014) Ecological production functions for biological control services in agricultural landscapes 
Methods in Ecology and Evolution 5:243-252 doi:10.1111/2041-210x.12149

Jonsson M, Kaartinen R, Straub CS (2017) Relationships between natural enemy diversity and biological control Current Opinion in Insect Science 20:1-6 doi:10.1016/j.cois.2017.01.001

Jonsson $\mathrm{M}$ et al. (2015) Experimental evidence that the effectiveness of conservation biological control depends on landscape complexity J Appl Ecol 52:1274-1282 doi:10.1111/1365-2664.12489

Jonsson M, Wratten SD, Landis DA, Gurr GM (2008) Recent advances in conservation biological control of arthropods by arthropods Biol Control 45:172-175 doi:10.1016/j.biocontrol.2008.01.006

Josso C, Le Ralec A, Raymond L, Saulais J, Baudry J, Poinsot D, Cortesero AM (2014) Effects of field and landscape variables on crop colonization and biological control of the cabbage root fly Delia radicum Landsc Ecol 28:1697-1715 doi:10.1007/s10980-013-9928-3

Junker RR, Blüthgen N, Brehm T, Binkenstein J, Paulus J, Schaefer HM, Stang M (2013) Specialization on traits as basis for the niche-breadth of flower visitors and as structuring mechanism of ecological networks Funct Ecol 27:329-341 doi:10.1111/1365-2435.12005

Kagata H, Ohgushi T (2006) Bottom-up trophic cascades and material transfer in terrestrial food webs Ecological Research 21:26-34 doi:10.1007/s11284-005-0124-Z

Kaplan I, Thaler JS (2011) Do plant defenses enhance or diminish prey suppression by omnivorous Heteroptera? Biol Control 59:53-60 doi:10.1016/j.biocontrol.2010.12.005

Kéfi S et al. (2012) More than a meal ... integrating non-feeding interactions into food webs Ecology Letters 15:291300 doi:10.1111/j.1461-0248.2011.01732.x

Kevan PG, Chittka L, Dyer AG (2001) Limits to the salience of ultraviolet: Lessons from colour vision in bees and birds J Exp Biol 204:2571-2580

Khan ZR, Pickett JA, van den Berg J, Wadhams LJ, Woodcock CM (2000) Exploiting chemical ecology and species diversity: stem borer and striga control for maize and sorghum in Africa Pest Manage Sci 56:957-962 doi:10.1002/1526-4998(200011)56:11<957::aid-ps236>3.0.co;2-t

Kienzle J, Foell M, Karrer E, Krismann A, Zebitz CPW (2014) Establishment of permanent weed strips with autochthonous nectar plants and their effect on the occurrence of aphid predators. Paper presented at the 16th International conference on organic fruit-growing, Stuttgart-Hohenheim, Germany

King RA, Vaughan IP, Bell JR, Bohan DA, Symondson WOC (2010) Prey choice by carabid beetles feeding on an earthworm community analysed using species- and lineage-specific PCR primers Mol Ecol 19:1721-1732 doi:10.1111/j.1365-294X.2010.04602.x

Kissling WD, Schleuning M (2015) Multispecies interactions across trophic levels at macroscales: retrospective and future directions Ecography 38:346-357 doi:10.1111/ecog.00819

Kopta T, Pokluda R, Psota V (2012) Attractiveness of flowering plants for natural enemies Horticultural Science 39:89-96

Kos $\mathrm{M}$ et al. (2014) Relative importance of plant-mediated bottom-up and top-down forces on herbivore abundance on Brassica oleracea Funct Ecol 25:1113-1124 doi:10.1111/j.1365-2435.2011.01871.x

Kos M, Kabouw P, Noordam R, Hendriks K, Vet LEM, van Loon JJA, Dicke M (2011) Prey-mediated effects of glucosinolates on aphid predators Ecol Entomol 36:377-388 doi:10.1111/j.1365-2311.2011.01282.x

Koss AM, Snyder WE (2005) Alternative prey disrupt biocontrol by a guild of generalist predators Biol Control 32:243-251 doi:10.1016/j.biocontrol.2004.10.002

Kranz J (2002) Labor- und Freilanduntersuchungen zur Attraktivität unterschiedlicher Wild- und Nutzpflanzen auf die Adulten verschiedener polyphager Prädatoren. Hohen Landwirtschaftlichen Fakultät der Rheinischen Friedrich-Wilhelms-Universität zu Bonn, Germany

Kromp B (1999) Carabid beetles in sustainable agriculture: a review on pest control efficacy, cultivation impacts and enhancement Agr Ecosyst Environ 74:187-228 doi:10.1016/s0167-8809(99)00037-7

Kühn I, Durka W, Klotz S (2004) BiolFlor - a new plant-trait database as a tool for plant invasion ecology Divers Distrib 10:363-365

Labuschagne L, Swanepoel LH, Taylor PJ, Belmain SR, Keith M (2016) Are avian predators effective biological control agents for rodent pest management in agricultural systems? Biol Control 101:94-102 doi:http://dx.doi.org/10.1016/j.biocontrol.2016.07.003

Laliberté É, Shipley B, Norton DA, Scott D (2012) Which plant traits determine abundance under long-term shifts in soil resource availability and grazing intensity? J Ecol 100:662-677 doi:10.1111/j.1365-2745.2011.01947.x

Landis DA, Menalled FD, Costamagna AC, Wilkinson TK (2005) Manipulating plant resources to enhance beneficial arthropods in agricultural landscapes Weed Sci 53:902-908 doi:10.1614/ws-04-050r1.1

Langer A, Hance T (2004) Enhancing parasitism of wheat aphids through apparent competition: a tool for biological control Agr Ecosyst Environ 102:205-212 doi:10.1016/j.agee.2003.07.005

Langoya LA, van Rijn PCJ (2008) The significance of floral resources for natural control of aphids Proceedings of the Netherlands Entomological Society Meeting 19:67-74

Laubertie EA, Wratten SD, Hemptinne JL (2012) The contribution of potential beneficial insectary plant species to adult hoverfly (Diptera: Syrphidae) fitness Biol Control 61:1-6 doi:10.1016/j.biocontrol.2011.12.010 
Lavorel S (2013) Plant functional effects on ecosystem services J Ecol 101:4-8 doi:10.1111/1365-2745.12031

Lavorel S, Garnier E (2002) Predicting changes in community composition and ecosystem functioning from plant traits: revisiting the Holy Grail Funct Ecol 16:545-556

Lavorel S et al. (2011) Using plant functional traits to understand the landscape distribution of multiple ecosystem services J Ecol 99:135-147 doi:10.1111/j.1365-2745.2010.01753.x

Lavorel S, McIntyre S, Landsberg J, Forbes TDA (1997) Plant functional classifications: from general groups to specific groups based on response to disturbance Trends in Ecology \& Evolution 12:474-478

Lavorel S et al. (2013) A novel framework for linking functional diversity of plants with other trophic levels for the quantification of ecosystem services J Veg Sci 24:942-948 doi:10.1111/jvs.12083

Law YH, Rosenheim JA (2011) Effects of combining an intraguild predator with a cannibalistic intermediate predator on a species-level trophic cascade Ecology 92:333-341 doi:10.1890/10-0156.1

Leather SR (1993) Overwintering in six arable aphid pests: a review with particular relevance to pest management J Appl Entomol 116:217-233 doi:10.1111/j.1439-0418.1993.tb01192.x

Lee JC, Heimpel GE (2005) Impact of flowering buckwheat on Lepidopteran cabbage pests and their parasitoids at two spatial scales Biol Control 34:290-301 doi:10.1016/j.biocontrol.2005.06.002

Lee JC, Heimpel GE, Leibee GL (2004) Comparing floral nectar and aphid honeydew diets on the longevity and nutrient levels of a parasitoid wasp Entomol Exp Appl 111:189-199 doi:10.1111/j.0013-8703.2004.00165.x

Lefcheck JS et al. (2015) Biodiversity enhances ecosystem multifunctionality across trophic levels and habitats Nature Communications 6:7 doi:10.1038/ncomms7936

Lefcheck JS, Duffy JE (2015) Multitrophic functional diversity predicts ecosystem functioning in experimental assemblages of estuarine consumers Ecology 96:2973-2983 doi:10.1890/14-1977.1

Lethmayer C (2000) Herbivore - Förderung von Schädlingen. In: Nentwig W (ed) Streifenförmige ökologische Ausgleichsflächen in der Kulturlandschaft: Ackerunkrautstreifen, Buntbrache, Feldränder. Verlag Agrarökologie, Bern - Hannover, pp 127-136

Lethmayer C, Nentwig W, Frank T (1997) Effects of weed strips on the occurrence of noxious coleopteran species (Nitidulidae, Chrysomelidae, Curculionidae) Z Pflanzenk Pflanzens-J Plant Dis Prot 104:75-92

Letourneau DK, Allen SGB, Stireman JO (2012) Perennial habitat fragments, parasitoid diversity and parasitism in ephemeral crops J Appl Ecol 49:1405-1416 doi:10.1111/1365-2664.12001

Letourneau DK et al. (2011) Does plant diversity benefit agroecosystems? A synthetic review Ecological Applications 21:9-21 doi:10.1890/09-2026.1

Letourneau DK, Jedlicka JA, Bothwell SG, Moreno CR (2009) Effects of natural enemy biodiversity on the suppression of arthropod herbivores in terrestrial ecosystems. In: Annual Review of Ecology Evolution and Systematics, vol 40. Annual Review of Ecology Evolution and Systematics. Annual Reviews, Palo Alto, pp 573-592. doi:10.1146/annurev.ecolsys.110308.120320

Lichtenberg EM et al. (2017) A global synthesis of the effects of diversified farming systems on arthropod diversity within fields and across agricultural landscapes Global Change Biol 23:4946-4957 doi:10.1111/gcb.13714

Liere H, Kim TN, Werling BP, Meehan TD, Landis DA, Gratton C (2015) Trophic cascades in agricultural landscapes: indirect effects of landscape composition on crop yield Ecological Applications 25:652-661 doi:10.1890/14-0570.1

Liere H, Larsen A (2010) Cascading trait-mediation: disruption of a trait-mediated mutualism by parasite-induced behavioral modification Oikos 119:1394-1400 doi:10.1111/j.1600-0706.2010.17985.x

Liman A-S, Dalin P, Björkman C (2016a) Enhanced leaf nitrogen status stabilizes omnivore population density Oecologia:1-9 doi:10.1007/s00442-016-3742-y

Liman AS, Eklund K, Björkman C (2016b) Predator refuges for conservation biological control in an intermediately disturbed system: the rise and fall of a simple solution J Appl Ecol 53:1823-1830 doi:10.1111/13652664.12709

Lindborg R (2007) Evaluating the distribution of plant life-history traits in relation to current and historical landscape configurations J Ecol 95:555-564

Lindström SAM, Herbertsson L, Rundlöf M, Bommarco R, Smith HG (2016) Experimental evidence that honeybees depress wild insect densities in a flowering crop Proceedings of the Royal Society B-Biological Sciences 283:8 doi:10.1098/rspb.2016.1641

Loeuille N, Barot S, Georgelin E, Kylafis G, Lavigne C, Guy W, David AB (2013) Eco-evolutionary dynamics of agricultural networks: implications for sustainable management. In: Advances in Ecological Research, vol Volume 49. Academic Press, pp 339-435. doi:http://dx.doi.org/10.1016/B978-0-12-420002-9.00006-8

Long EY, Finke DL (2014) Contribution of predator identity to the suppression of herbivores by a diverse predator assemblage Environ Entomol 43:569-576 doi:10.1603/en13179

Long EY, Finke DL (2015) Predators indirectly reduce the prevalence of an insect-vectored plant pathogen independent of predator diversity Oecologia 177:1067-1074 doi:10.1007/s00442-014-3194-1

Loranger J et al. (2013) Predicting invertebrate herbivory from plant traits: Polycultures show strong nonadditive effects Ecology 94:1499-1509 doi:10.1890/12-2063.1 
Loranger J et al. (2016) Recasting the dynamic equilibrium model through a functional lens: the interplay of traitbased community assembly and climate J Ecol:n/a-n/a doi:10.1111/1365-2745.12536

Losey JE, Denno RF (1998) Positive predator-predator interactions: enhanced predation rates and synergistic suppression of aphid populations Ecology 79:2143-2152 doi:10.1890/00129658(1998)079[2143:pppiep]2.0.co;2

Lu Y, Wu K, Jiang Y, Guo Y, Desneux N (2012) Widespread adoption of Bt cotton and insecticide decrease $\begin{array}{llll}\text { promotes } & \text { biocontrol } & \text { services } & \text { Nature }\end{array}$ doi:http://www.nature.com/nature/journal/v487/n7407/abs/nature11153.html - supplementary-information

Luka H, Lutz M, Blick T, Pfiffner L (2001) Einfluss von eingesäten Wildblumenstreifen auf die epigäischen Laufkäfer und Spinnen (Carabidae und Araneae) in der intensiv genutzten Agrarlandschaft "Grosses Moos", Schweiz Peckiana:45-60

Lundgren JG, Fausti SW (2015) Trading biodiversity for pest problems Science Advances 1 doi:10.1126/sciadv.1500558

Lundgren JG, Fergen JK (2014) Predator community structure and trophic linkage strength to a focal prey Mol Ecol 23:3790-3798 doi:10.1111/mec. 12700

Lys JA, Nentwig W (1992a) Augmentation of beneficial arthropods by strip-management. 4. Surface-activity, movements and activity-density of abundant carabid beetles in a cereal field Oecologia 92:373-382 doi:10.1007/bf00317463

Lys JA, Nentwig W (1992b) Förderung von Laufkäfern (Coleoptera, Carabidae) in einem Getreidefeld durch Künstlich Angesäte Krautstreifen Mitteilungen der Deutschen Gesellschaft für Allgemeine und Angewandte Entomologie 8:128-132

Lys JA, Nentwig W (1994) Improvement of the overwintering sites for Carabidae, Staphylinidae and Aranae by strip-management in a cereal field

Pedobiologia 38:238-242

Mace KC, Mills NJ (2017) Connecting natural enemy metrics to biological control activity for aphids in California walnuts Biol Control 106:16-26 doi:10.1016/j.biocontrol.2016.11.009

Macfadyen S, Craze PG, Polaszek A, van Achterberg K, Memmott J (2011) Parasitoid diversity reduces the variability in pest control services across time on farms Proceedings of the Royal Society B-Biological Sciences 278:3387-3394 doi:10.1098/rspb.2010.2673

Macfadyen S, Gibson R, Raso L, Sint D, Traugott M, Memmott J (2009) Parasitoid control of aphids in organic and conventional farming systems Agr Ecosyst Environ 133:14-18 doi:10.1016/j.agee.2009.04.012

MacLeod A (1999) Attraction and retention of Episyrphus balteatus DeGeer (Diptera : Syrphidae) at an arable field margin with rich and poor floral resources Agr Ecosyst Environ 73:237-244 doi:10.1016/s01678809(99)00051-1

MacLeod A, Wratten SD, Sotherton NW, Thomas MB (2004) 'Beetle banks' as refuges for beneficial arthropods in farmland: long-term changes in predator communities and habitat Agric For Entomol 6:147-154 doi:10.1111/j.1461-9563.2004.00215.x

Mair J, Port GR (2001) Predation on the slug Deroceras reticulatum by the carabid beetles Pterostichus madidus and Nebria brevicollis in the presence of alternative prey Agric For Entomol 3:169-174 doi:10.1046/j.14619555.2001.00102.x

Malézieux E et al. (2009) Mixing plant species in cropping systems: concepts, tools and models. A review Agronomy for Sustainable Development 29:43-62 doi:10.1051/agro:2007057

Mansion-Vaquié A, Ferrante M, Cook SM, Pell JK, Lövei GL (2017) Manipulating field margins to increase predation intensity in fields of winter wheat (Triticum aestivum) J Appl Entomol 141:600-611 doi:10.1111/jen.12385

Marc P, Canard A, Ysnel F (1999) Spiders (Araneae) useful for pest limitation and bioindication Agr Ecosyst Environ 74:229-273 doi:10.1016/s0167-8809(99)00038-9

Marko V, Jenser G, Kondorosy E, Abraham L, Balazs K (2013) Flowers for better pest control? The effects of apple orchard ground cover management on green apple aphids (Aphis spp.) (Hemiptera: Aphididae), their predators and the canopy insect community Biocontrol Sci Technol 23:126-145 doi:10.1080/09583157.2012.743972

Marshall EJP, Brown VK, Boatman ND, Lutman PJW, Squire GR, Ward LK (2003) The role of weeds in supporting biological diversity within crop fields Weed Res 43:77-89

Martin AR, Rapidel B, Roupsard O, Van den Meersche K, Virginio ED, Barrios M, Isaac ME (2017) Intraspecific trait variation across multiple scales: the leaf economics spectrum in coffee Funct Ecol 31:604-612 doi:10.1111/1365-2435.12790

Massey FP, Ennos AR, Hartley SE (2006) Silica in grasses as a defence against insect herbivores: contrasting effects on folivores and a phloem feeder J Anim Ecol 75:595-603 doi:10.1111/j.1365-2656.2006.01082.x

Mayhew PJ (2016) Comparing parasitoid life histories Entomol Exp Appl 159:147-162 doi:10.1111/eea.12411

Medeiros MA, Sujii ER, Morais HC (2009) Effect of plant diversification on abundance of South American tomato 
pinworm and predators in two cropping systems Horticultura Brasileira 27:300-306

Meek B, Loxton D, Sparks T, Pywell R, Pickett H, Nowakowski M (2002) The effect of arable field margin composition on invertebrate biodiversity Biol Conserv 106:259-271 doi:10.1016/s0006-3207(01)00252-x

Messelink GJ, Van Maanen R, Van Holstein-Saj R, Sabelis MW, Janssen A (2010) Pest species diversity enhances control of spider mites and whiteflies by a generalist phytoseiid predator Biocontrol 55:387-398 doi:10.1007/s10526-009-9258-1

Meyer B, Jauker F, Steffan-Dewenter I (2009) Contrasting resource-dependent responses of hoverfly richness and density to landscape structure Basic and Applied Ecology 10:178-186 doi:10.1016/j.baae.2008.01.001

Mitchell C, Brennan RM, Graham J, Karley AJ (2016) Plant defense against herbivorous pests: exploiting resistance and tolerance traits for sustainable crop protection Frontiers in Plant Science 7:8 doi:10.3389/fpls.2016.01132

Montoya JM, Woodward G, Emmerson MC, Sole RV (2009) Press perturbations and indirect effects in real food webs Ecology 90:2426-2433 doi:10.1890/08-0657.1

Mooney KA, Singer MS (2012) Plant effects on herbivore-enemy interactions in natural systems. In: Ohgushi T, Schmitz O, Holt RD (eds) Trait-Mediated Indirect Interactions. Ecological and Evolutionary Perspectives. Cambridge University Press, Cambridge pp pp. 107-130

Morandin LA, Long RF, Kremen C (2016) Pest control and pollination cost-benefit analysis of hedgerow restoration in a simplified agricultural landscape J Econ Entomol 109:1020-1027 doi:10.1093/jee/tow086

Moretti $\mathrm{M}$ et al. (2013) Linking traits between plants and invertebrate herbivores to track functional effects of landuse changes J Veg Sci 24:949-962 doi:10.1111/jvs.12022

Moretti M et al. (2017) Handbook of protocols for standardized measurement of terrestrial invertebrate functional traits Funct Ecol 31:558-567 doi:10.1111/1365-2435.12776

Moretti M, Legg C (2009) Combining plant and animal traits to assess community functional responses to disturbance Ecography 32:299-309 doi:10.1111/j.1600-0587.2008.05524.x

Mouillot D et al. (2013) Rare species support vulnerable functions in high-diversity ecosystems PLoS Biol 11:11 doi:10.1371/journal.pbio.1001569

Mouillot D, Villéger S, Scherer-Lorenzen M, Mason NWH (2011) Functional structure of biological communities predicts ecosystem multifunctionality Plos One 6:9 doi:10.1371/journal.pone.0017476

Nentwig W (1992) Die nützlingsfördernde Wirkung von Unkräutern in angesäten Unkraustreifen Zeitschrift für Pflanzenkrankheiten und Pflanzenschutz 13:33-40

Nentwig W (1993) Nützlingsförderung in Agrarökosystemen Verhandlungen der Gesellschaft für Ökologie Band 22:9-14

Nentwig W (2002) Weedy plant species and their beneficial arthropods: potential for manipulation in field crops. In: Pickett CH, Bugg RL (eds) Enhancing biological control. University of California Press, Berkeley, LosAngeles, London, pp 49-71

Nesbit CM, Menendez R, Roberts MR, Wilby A (2016) Associational resistance or susceptibility: the indirect interaction between chemically-defended and non-defended herbivore prey via a shared predator Oikos 125:1802-1811 doi:10.1111/oik.03157

Nesbit CM, Wilby A, Roberts MR, Menéndez R (2015) Selection of aphid prey by a generalist predator: do prey chemical defences matter? Ecol Entomol 40:767-775 doi:10.1111/een.12253

Nofemela RS (2013) The effect of obligate hyperparasitoids on biological control: Differential vulnerability of primary parasitoids to hyperparasitism can mitigate trophic cascades Biol Control 65:218-224 doi:10.1016/j.biocontrol.2013.02.003

Noordijk J, Musters CJM, van Dijk J, de Snoo GR (2010) Invertebrates in field margins: taxonomic group diversity and functional group abundance in relation to age Biodivers Conserv 19:3255-3268 doi:10.1007/s10531010-9890-1

Norris RF, Kogan M (2000) Interactions between weeds, arthropod pests, and their natural enemies in managed ecosystems Weed Sci 48:94-158 doi:10.1614/0043-1745(2000)048[0094:ibwapa]2.0.co;2

Norris RF, Kogan M (2005) Ecology of interactions between weeds and arthropods. In: Annual Review of Entomology, vol 50. Annual Review of Entomology. Annual Reviews, Palo Alto, pp 479-503. doi:10.1146/annurev.ento.49.061802.123218

Northfield TD, Crowder DW, Takizawa T, Snyder WE (2014) Pairwise interactions between functional groups improve biological control Biol Control 78:49-54 doi:10.1016/j.biocontrol.2014.07.008

Northfield TD, Snyder GB, Ives AR, Snyder WE (2010) Niche saturation reveals resource partitioning among consumers Ecology Letters 13:338-348 doi:10.1111/j.1461-0248.2009.01428.x

Nyffeler M, Breene RG, Dean DA, Sterling WL (1990) Spiders as predators of arthropod eggs J Appl Entomol 109:490-501

Nyffeler M, Sunderland KD (2003) Composition, abundance and pest control potential of spider communities in agroecosystems: a comparison of European and US studies Agr Ecosyst Environ 95:579-612 doi:10.1016/s0167-8809(02)00181-0 
O'Neal ME, Zontek EL, Szendrei Z, Landis DA, Isaacs R (2005) Ground predator abundance affects prey removal in highbush blueberry (Vaccinium corymbosum) fields and can be altered by aisle ground covers Biocontrol 50:205-222 doi:10.1007/s10526-004-0676-9

Olson DM, Wäckers FL (2007) Management of field margins to maximize multiple ecological services J Appl Ecol 44:13-21 doi:10.1111/j.1365-2664.2006.01241.x

Orford KA, Murray PJ, Vaughan IP, Memmott J (2016) Modest enhancements to conventional grassland diversity improve the provision of pollination services J Appl Ecol 53:906-915 doi:10.1111/1365-2664.12608

Osborne P (1960) Observations on the natural enemies of Meligethes aeneus (F.) and M. viridescens (F.) [Coleoptera: Nitidulidae] Parasitology 50:91-110

Östman Ö, Ekbom B, Bengtsson J (2003) Yield increase attributable to aphid predation by ground-living polyphagous natural enemies in spring barley in Sweden Ecol Econ 45:149-158 doi:10.1016/s09218009(03)00007-7

Otto SB, Berlow EL, Rank NE, Smiley J, Brose U (2008) Predator diversity and identity drive interaction strength and trophic cascades in a food web Ecology 89:134-144 doi:10.1890/07-0066.1

Pannwitt H, Westerman PR, de Mol F, Selig C, Gerowitt B (2017) Biological control of weed patches by seed predators; responses to seed density and exposure time Biol Control 108:1-8 doi:10.1016/j.biocontrol.2017.01.016

Parolin P, Bresch C, Poncet C, Desneux N (2012) Functional characteristics of secondary plants for increased pest management Int J Pest Manage 58:368-376 doi:10.1080/09670874.2012.734869

Patt JM, Hamilton GC, Lashomb JH (1997) Foraging success of parasitoid wasps on flowers: Interplay of insect morphology, floral architecture and searching behavior Entomol Exp Appl 83:21-30 doi:10.1046/j.15707458.1997.00153.x

Pearson CV, Massad TJ, Dyer LA (2008) Diversity cascades in alfalfa fields: From plant quality to agroecosystem diversity Environ Entomol 37:947-955 doi:10.1603/0046-225x(2008)37[947:dciaff]2.0.co;2

Pearson DE (2010) Trait- and density-mediated indirect interactions initiated by an exotic invasive plant Autogenic ecosystem engineer Am Nat 176:394-403 doi:10.1086/656274

Peeters PJ, Sanson G, Read J (2007) Leaf biomechanical properties and the densities of herbivorous insect guilds Funct Ecol 21:246-255 doi:10.1111/j.1365-2435.2006.01223.x

Pekár S, Michalko R, Loverre P, Líznarová E, Černecká L' (2015) Biological control in winter: novel evidence for the importance of generalist predators J Appl Ecol:n/a-n/a doi:10.1111/1365-2664.12363

Pell JK, Baverstock J, Roy HE, Ware RL, Majerus MEN (2008) Intraguild predation involving Harmonia axyridis: a review of current knowledge and future perspectives Biocontrol 53:147-168 doi:10.1007/s10526-007-9125$\mathrm{X}$

Peralta G, Frost CM, Rand TA, Didham RK, Tylianakis JM (2014) Complementarity and redundancy of interactions enhance attack rates and spatial stability in host-parasitoid food webs Ecology 95:1888-1896

Pérez-Harguindeguy N, Díaz S, Vendramini F, Cornelissen JHC, Gurvich DE, Cabido M (2003) Leaf traits and herbivore selection in the field and in cafeteria experiments Austral Ecol 28:642-650 doi:10.1046/j.14429993.2003.01321.x

Petermann JS, Muller CB, Weigelt A, Weisser WW, Schmid B (2010) Effect of plant species loss on aphidparasitoid communities J Anim Ecol 79:709-720 doi:10.1111/j.1365-2656.2010.01674.x

Petersen LF, Woltz JM (2015) Diel variation in the abundance and composition of the predator assemblages feeding on aphid-infested soybean Biocontrol 60:209-219 doi:10.1007/s10526-014-9631-6

Peterson JA, Ode PJ, Oliveira-Hofman C, Harwood JD (2016) Integration of plant defense traits with biological control of arthropod pests: challenges and opportunities Frontiers in Plant Science 7:23 doi:10.3389/fpls.2016.01794

Pey B et al. (2014) Current use of and future needs for soil invertebrate functional traits in community ecology Basic and Applied Ecology 15:194-206 doi:10.1016/j.baae.2014.03.007

Pfannenstiel RS, Patt JM (2012) Feeding on nectar and honeydew sugars improves survivorship of two nocturnal cursorial spiders Biol Control 63:231-236 doi:10.1016/j.biocontrol.2012.07.013

Pfiffner L, Luka H, Schlatter C, Juen A, Traugott M (2009) Impact of wildflower strips on biological control of cabbage lepidopterans Agr Ecosyst Environ 129:310-314 doi:10.1016/j.agee.2008.10.003

Pfiffner L, Wyss E (2004) Use of sown wildflower strips to enhance natural enemies of agricultural pests. In: Ecological engineering for pest management: advances in habitat manipulation for arthropods. CABI Publishing, Wallingford, UK, pp 165-186

Philips CR (2013) Food webs and phenology models: evaluating the efficacy of ecologically-based insect pest management in different agroecosystems. Virginia Polytechnic Institute and State University

Phillips BW, Gardiner MM (2016) Does local habitat management or large-scale landscape composition alter the biocontrol services provided to pumpkin agroecosystems? Biol Control 92:181-194 doi:10.1016/j.biocontrol.2015.10.001

Podgaiski LR, Joner F, Lavorel S, Moretti M, Ibanez S, Mendonca MD, Pillar VD (2013) Spider trait assembly 
patterns and resilience under fire-induced vegetation change in South Brazilian grasslands PLoS One 8:11 doi:10.1371/journal.pone.0060207

Poelman EH, van Loon JJA, Dicke M (2008) Consequences of variation in plant defense for biodiversity at higher trophic levels Trends Plant Sci 13:534-541 doi:10.1016/j.tplants.2008.08.003

Poeydebat C, Tixier P, Chabrier C, de Bellaire LdL, Vargas R, Daribo M-O, Carval D (2017a) Does plant richness alter multitrophic soil food web and promote plant-parasitic nematode regulation in banana agroecosystems? Applied Soil Ecology 117-118:137-146 doi:https://doi.org/10.1016/j.apsoil.2017.04.017

Poeydebat C, Tixier P, De Bellaire LD, Carval D (2017b) Plant richness enhances banana weevil regulation in a tropical agroecosystem by affecting a multitrophic food web Biol Control 114:125-132 doi:10.1016/j.biocontrol.2017.08.009

Pontin DR, Wade MR, Kehrli P, Wratten SD (2006) Attractiveness of single and multiple species flower patches to beneficial insects in agroecosystems Ann Appl Biol 148:39-47 doi:10.1111/j.1744-7348.2005.00037.x

Porcel M, Ruano F, Cotes B, Pena A, Campos M (2013) Agricultural Management Systems Affect the Green Lacewing Community (Neuroptera: Chrysopidae) in Olive Orchards in Southern Spain Environ Entomol 42:97-106 doi:10.1603/en11338

Potts SG, Vulliamy B, Roberts S, O'Toole C, Dafni A, Ne'eman G, Willmer PG (2004) Nectar resource diversity organises flower-visitor community structure Entomol Exp Appl 113:103-107 doi:10.1111/j.00138703.2004.00212.x

Powell W, Pickett JA (2003) Manipulation of parasitoids for aphid pest management: progress and prospects Pest Manage Sci 59:149-155 doi:10.1002/ps.550

Pozzebon A, Loeb GM, Duso C (2015) Role of supplemental foods and habitat structural complexity in persistence and coexistence of generalist predatory mites Scientific Reports 5 doi:10.1038/srep14997

Prasad RP, Snyder WE (2006) Diverse trait-mediated interactions in a multi-predator, multi-prey community Ecology 87:1131-1137 doi:10.1890/0012-9658(2006)87[1131:dtiiam]2.0.co;2

Prasad RP, Snyder WE (2010) A non-trophic interaction chain links predators in different spatial niches Oecologia 162:747-753 doi:10.1007/s00442-009-1486-7

Prasifka JR, Schmidt NP, Kohler KA, O'Neal ME, Hellmich RL, Singer JW (2006) Effects of living mulches on predator abundance and sentinel prey in a corn-soybean-forage rotation Environ Entomol 35:1423-1431 doi:10.1603/0046-225x(2006)35[1423:eolmop]2.0.co;2

Price PW (2002) Resource-driven terrestrial interaction webs Ecological Research 17:241-247 doi:10.1046/j.14401703.2002.00483.x

Pywell RF, James KL, Herbert I, Meek WR, Carvell C, Bell D, Sparks TH (2005) Determinants of overwintering habitat quality for beetles and spiders on arable farmland Biol Conserv 123:79-90 doi:10.1016/j.biocon.2004.10.010

Pywell RF et al. (2006) Effectiveness of new agri-environment schemes in providing foraging resources for bumblebees in intensively farmed landscapes Biol Conserv 129:192-206 doi:10.1016/j.biocon.2005.10.034

Quijas S, Schmid B, Balvanera P (2010) Plant diversity enhances provision of ecosystem services: A new synthesis Basic and Applied Ecology 11:582-593 doi:10.1016/j.baae.2010.06.009

Ramsden M, Menendez R, Leather S, Wäckers F (2016) Do natural enemies really make a difference? Field scale impacts of parasitoid wasps and hoverfly larvae on cereal aphid populations Agric For Entomol:n/a-n/a doi:10.1111/afe.12191

Ramsden MW, Menéndez R, Leather SR, Wäckers F (2015) Optimizing field margins for biocontrol services: The relative role of aphid abundance, annual floral resources, and overwinter habitat in enhancing aphid natural enemies Agr Ecosyst Environ 199:94-104 doi:10.1016/j.agee.2014.08.024

Rand TA, Tylianakis JM, Tscharntke T (2006) Spillover edge effects: the dispersal of agriculturally subsidized insect natural enemies into adjacent natural habitats Ecology Letters 9:603-614 doi:10.1111/j.14610248.2006.00911.x

Ratnadass A, Fernandes P, Avelino J, Habib R (2012) Plant species diversity for sustainable management of crop pests and diseases in agroecosystems: a review Agronomy for Sustainable Development 32:273-303 doi:10.1007/s13593-011-0022-4

Raymond L, Plantegenest M, Gagic V, Navasse Y, Lavandero B (2016) Aphid parasitoid generalism: development, assessment, and implications for biocontrol J Pest Sci 89:7-20 doi:10.1007/s10340-015-0687-6

Raymond L, Sarthou JP, Plantegenest M, Gauffre B, Ladet S, Vialatte A (2014) Immature hoverflies overwinter in cultivated fields and may significantly control aphid populations in autumn Agr Ecosyst Environ 185:99105 doi:10.1016/j.agee.2013.12.019

Rebek EJ, Sadof CS, Hanks LM (2005) Manipulating the abundance of natural enemies in ornamental landscapes with floral resource plants Biol Control 33:203-216 doi:10.1016/j.biocontrol.2005.02.011

Requier F, Odoux JF, Tamic T, Moreau N, Henry M, Decourtye A, Bretagnolle V (2015) Honey bee diet in intensive farmland habitats reveals an unexpectedly high flower richness and a major role of weeds Ecological Applications 25:881-890 doi:10.1890/14-1011.1 
Ribera I, Dolédec S, Downie IS, Foster GN (2001) Effect of land disturbance and stress on species traits of ground beetles assemblages Ecology 82:1112-1129 doi:10.1890/0012-9658(2001)082[1112:EOLDAS]2.0.CO;2

Ricou C, Schneller C, Amiaud B, Plantureux S, Bockstaller C (2014) A vegetation-based indicator to assess the pollination value of field margin flora Ecol Indicators 45:320-331 doi:http://dx.doi.org/10.1016/j.ecolind.2014.03.022

Riggi LG, Gagic V, Rusch A, Malsher G, Ekbom B, Bommarco R (2017) Pollen beetle mortality is increased by ground-dwelling generalist predators but not landscape complexity Agr Ecosyst Environ 250:133-142 doi:10.1016/j.agee.2017.06.039

Robinson JV (1981) The effect of architectural variation in habitat on a spider community - An experimental field study Ecology 62:73-80 doi:10.2307/1936670

Rodríguez MÁ, Hawkins BA (2000) Diversity, function and stability in parasitoid communities Ecology Letters 3:35-40 doi:10.1046/j.1461-0248.2000.00115.x

Rohr JR et al. (2015) Predator diversity, intraguild predation, and indirect effects drive parasite transmission Proc Natl Acad Sci U S A 112:3008-3013 doi:10.1073/pnas.1415971112

Roland J, Taylor PD (1997) Insect parasitoid species respond to forest structure at different spatial scales Nature 386:710-713 doi:10.1038/386710a0

Rollin O, Benelli G, Benvenuti S, Decourtye A, Wratten SD, Canale A, Desneux N (2016) Weed-insect pollinator networks as bio-indicators of ecological sustainability in agriculture. A review Agronomy for Sustainable Development 36:22 doi:10.1007/s13593-015-0342-x

Rollin O, Bretagnolle V, Decourtye A, Aptel J, Michel N, Vaissière BE, Henry M (2013) Differences of floral resource use between honey bees and wild bees in an intensive farming system Agr Ecosyst Environ 179:78-86 doi:10.1016/j.agee.2013.07.007

Roschewitz I, Hucker M, Tscharntke T, Thies C (2005) The influence of landscape context and farming practices on parasitism of cereal aphids Agr Ecosyst Environ 108:218-227 doi:10.1016/j.agee.2005.02.005

Rosenheim JA (1998) Higher-order predators and the regulation of insect herbivore populations Annu Rev Entomol 43:421-447 doi:10.1146/annurev.ento.43.1.421

Rouabah A, Lasserre-Joulin F, Amiaud B, Plantureux S (2014) Emergent effects of ground beetles size diversity on the strength of prey suppression Ecol Entomol 39:47-57 doi:10.1111/een.12064

Rouabah A, Villerd J, Amiaud B, Plantureux S, Lasserre-Joulin Fo (2015) Response of carabid beetles diversity and size distribution to the vegetation structure within differently managed field margins Agr Ecosyst Environ 200:21-32 doi:http://dx.doi.org/10.1016/j.agee.2014.10.011

Roubinet E, Birkhofer K, Malsher G, Staudacher K, Ekbom B, Traugott M, Jonsson M (2017) Diet of generalist predators reflects effects of cropping period and farming system on extra- and intraguild prey Ecological Applications 27:1167-1177 doi:10.1002/eap.1510

Roumegous S (2012) Impact of natural infrastructures surrounding arable fields on two arthropods guilds : Carabidae and Syrphidae. Msc Thesis Report, WU BFS Group \& ISARA Lyon, Chambre régionale d'agriculture de Charente-Maritime

Ruppert V (1992) Einfluss blütenreicher Feldrandstrukturen auf die Dichte blütenbesuchender Nutzinsekten insbesondere der Syrphidae. vol PhD thesis. Agrarökologie; Bd. 8. Bern: Haupt, 1992,

Rusch A, Binet D, Delbac L, Thiéry D (2016a) Local and landscape effects of agricultural intensification on Carabid community structure and weed seed predation in a perennial cropping system Landsc Ecol 31:2163-2174 doi:10.1007/s10980-016-0390-x

Rusch A, Birkhofer K, Bommarco R, Smith HG, Ekbom B (2015) Predator body sizes and habitat preferences predict predation rates in an agroecosystem Basic and Applied Ecology 16:250-259 doi:10.1016/j.baae.2015.02.003

Rusch A et al. (2016b) Agricultural landscape simplification reduces natural pest control: a quantitative synthesis Agr Ecosyst Environ 221:198-204 doi:http://dx.doi.org/10.1016/j.agee.2016.01.039

Rusch A, Valantin-Morison M, Roger-Estrade J, Sarthou JP (2012) Local and landscape determinants of pollen beetle abundance in overwintering habitats Agric For Entomol 14:37-47 doi:10.1111/j.14619563.2011.00547.x

Rusch A, Valantin-Morison M, Sarthou JP, Roger-Estrade J (2011) Multi-scale effects of landscape complexity and crop management on pollen beetle parasitism rate Landsc Ecol 26:473-486 doi:10.1007/s10980-011-9573-7

Salisbury A, Armitage J, Bostock H, Perry J, Tatchell M, Thompson K (2015) Enhancing gardens as habitats for flower-visiting aerial insects (pollinators): should we plant native or exotic species? J Appl Ecol 52:11561164 doi:10.1111/1365-2664.12499

Salveter R (1998) The influence of sown herb strips and spontaneous weeds on the larval stages of aphidophagous hoverflies (Dipt., Syrphidae) Journal of Applied Entomology-Zeitschrift Fur Angewandte Entomologie 122:103-114

Samu F, Beleznai O, Tholt G (2013) A potential spider natural enemy against virus vector leafhoppers in agricultural mosaic landscapes - Corroborating ecological and behavioral evidence Biol Control 67:390-396 
doi:10.1016/j.biocontrol.2013.08.016

Samu F, Németh J, Kiss B (1997) Assessment of the efficiency of a hand-held suction device for sampling spiders: improved density estimation or oversampling? Ann Appl Biol 130:371-378 doi:10.1111/j.17447348.1997.tb06840.x

Sauve AMC, Thebault E, Pocock MJO, Fontaine C (2016) How plants connect pollination and herbivory networks and their contribution to community stability Ecology 97:908-917 doi:10.1890/15-0132.1

Schädler M, Jung G, Auge H, Brandl R (2003) Palatability, decomposition and insect herbivory: patterns in a successional old-field plant community Oikos 103:121-132 doi:10.1034/j.1600-0706.2003.12659.x

Schaffers AP, Raemakers IP, Sykora KV, Ter Braak CJF (2008) Arthropod assemblages are best predicted by plant species composition Ecology 89:782-794 doi:10.1890/07-0361.1

Scheid BE, Thies C, Tscharntke T (2011) Enhancing rape pollen beetle parasitism within sown flower fields along a landscape complexity gradient Agric For Entomol 13:173-179 doi:10.1111/j.1461-9563.2010.00516.x

Schellhorn NA, Bellati J, Paull CA, Maratos L (2008) Parasitoid and moth movement from refuge to crop Basic and Applied Ecology 9:691-700 doi:10.1016/j.baae.2007.12.010

Scheper J et al. (2015) Local and landscape-level floral resources explain effects of wildflower strips on wild bees across four European countries J Appl Ecol 52:1165-1175 doi:10.1111/1365-2664.12479

Schleuning M, Fründ J, García D (2015) Predicting ecosystem functions from biodiversity and mutualistic networks: an extension of trait-based concepts to plant-animal interactions Ecography 38:380-392 doi:10.1111/ecog.00983

Schmidt JM, Barney SK, Williams MA, Bessin RT, Coolong TW, Harwood JD (2014) Predator-prey trophic relationships in response to organic management practices Mol Ecol 23:3777-3789 doi:10.1111/mec.12734

Schmidt MH, Tscharntke T (2005a) Landscape context of sheetweb spider (Araneae : Linyphiidae) abundance in cereal fields J Biogeogr 32:467-473 doi:10.1111/j.1365-2699.2004.01244.x

Schmidt MH, Tscharntke T (2005b) The role of perennial habitats for Central European farmland spiders Agr Ecosyst Environ 105:235-242 doi:10.1016/j.agee.2004.03.009

Schmidt-Entling MH, Döbeli J (2009) Sown wildflower areas to enhance spiders in arable fields Agr Ecosyst Environ 133:19-22 doi:10.1016/j.agee.2009.04.015

Schmitz OJ, Buchkowski RW, Burghardt KT, Donihue CM (2015) Functional traits and trait-mediated interactions: connecting community-level interactions with ecosystem functioning. In: Samraat Pawar GW, Anthony ID (eds) Advances in Ecological Research, vol Volume 52. Academic Press, pp 319-343. doi:http://dx.doi.org/10.1016/bs.aecr.2015.01.003

Schneider G, Krauss J, Boetzl FA, Fritze MA, Steffan-Dewenter I (2016) Spillover from adjacent crop and forest habitats shapes carabid beetle assemblages in fragmented semi-natural grasslands Oecologia 182:1141-1150 doi:10.1007/s00442-016-3710-6

Settle WH et al. (1996) Managing tropical rice pests through conservation of generalist natural enemies and alternative prey Ecology 77:1975-1988 doi:10.2307/2265694

Shackelford G, Steward PR, Benton TG, Kunin WE, Potts SG, Biesmeijer JC, Sait SM (2013) Comparison of pollinators and natural enemies: a meta-analysis of landscape and local effects on abundance and richness in crops Biological Reviews 88:1002-1021 doi:10.1111/brv.12040

Shennan C (2008) Biotic interactions, ecological knowledge and agriculture Philosophical Transactions of the Royal Society B-Biological Sciences 363:717-739 doi:10.1098/rstb.2007.2180

Sih A, Englund G, Wooster D (1998) Emergent impacts of multiple predators on prey Trends in Ecology \& Evolution 13:350-355 doi:10.1016/s0169-5347(98)01437-2

Silva EB, Franco JC, Vasconcelos T, Branco M (2010) Effect of ground cover vegetation on the abundance and diversity of beneficial arthropods in citrus orchards Bull Entomol Res 100:489-499 doi:10.1017/s0007485309990526

Simpson M et al. (2011) Attract and reward: combining chemical ecology and habitat manipulation to enhance biological control in field crops J Appl Ecol 48:580-590 doi:10.1111/j.1365-2664.2010.01946.x

Singer MS, Clark RE, Lichter-Marck IH, Johnson ER, Mooney KA (2017) Predatory birds and ants partition caterpillar prey by body size and diet breadth J Anim Ecol 86:1363-1371 doi:10.1111/1365-2656.12727

Sivinski J, Wahl D, Holler T, Al Dobai S, Sivinski R (2011) Conserving natural enemies with flowering plants: Estimating floral attractiveness to parasitic Hymenoptera and attraction's relationship to flower and plant morphology Biol Control 58:208-214 doi:10.1016/j.biocontrol.2011.05.002

Snyder WE, Snyder GB, Finke DL, Straub CS (2006) Predator biodiversity strengthens herbivore suppression Ecology Letters 9:789-796 doi:10.1111/j.1461-0248.2006.00922.x

Snyder WE, Wise DH (1999) Predator interference and the establishment of generalist predator populations for biocontrol Biol Control 15:283-292 doi:10.1006/bcon.1999.0723

Sorribas J, González S, Domínguez-Gento A, Vercher R (2016) Abundance, movements and biodiversity of flying predatory insects in crop and non-crop agroecosystems Agronomy for Sustainable Development 36:9 doi:10.1007/s13593-016-0360-3 
Southwood TRE (1977) Habitat, the templet for ecological strategies? J Anim Ecol 46:337-365

Speight MR, Lawton JH (1976) Influence of weed-cover on mortality imposed on artificial prey by predatory ground beetles in cereal fields (Ecologia 23:211-223 doi:10.1007/bf00361237

Stang M, Klinkhamer PGL, van der Meijden E (2006) Size constraints and flower abundance determine the number of interactions in a plant-flower visitor web Oikos 112:111-121 doi:10.1111/j.0030-1299.2006.14199.x

Stang M, Klinkhamer PGL, Waser NM, Stang I, van der Meijden E (2009) Size-specific interaction patterns and size matching in a plant-pollinator interaction web Ann Bot 103:1459-1469 doi:10.1093/aob/mcp027

Steffan SA, Snyder WE (2010) Cascading diversity effects transmitted exclusively by behavioral interactions Ecology 91:2242-2252 doi:10.1890/09-0787.1

Stephens CJ, Schellhorn NA, Wood GM, Austin AD (2006) Parasitic wasp assemblages associated with native and weedy plant species in an agricultural landscape Aust $\mathrm{J}$ Entomol 45:176-184 doi:10.1111/j.14406055.2006.00519.x

Stiling P, Cornelissen T (2005) What makes a successful biocontrol agent? A meta-analysis of biological control agent performance Biol Control 34:236-246 doi:10.1016/j.biocontrol.2005.02.017

Storkey J, Brooks D, Haughton A, Hawes C, Smith BM, Holland JM (2013) Using functional traits to quantify the value of plant communities to invertebrate ecosystem service providers in arable landscapes J Ecol 101:3846 doi:10.1111/1365-2745.12020

Storkey J, Döring T, Baddeley J, Collins R, Roderick S, Jones H, Watson C (2015) Engineering a plant community to deliver multiple ecosystem services Ecological Applications 25:1034-1043 doi:10.1890/14-1605.1.sm

Straub CS, Finke DL, Snyder WE (2008) Are the conservation of natural enemy biodiversity and biological control compatible goals? Biol Control 45:225-237 doi:http://dx.doi.org/10.1016/j.biocontrol.2007.05.013

Sutter L, Albrecht M (2016) Synergistic interactions of ecosystem services: florivorous pest control boosts crop yield increase through insect pollination Proceedings of the Royal Society B-Biological Sciences 283:8 doi: $10.1098 /$ rspb.2015.2529

Symondson WOC et al. (2006) Biodiversity vs. biocontrol: positive and negative effects of alternative prey on control of slugs by carabid beetles Bull Entomol Res 96:637-645 doi:10.1079/ber2006467

Symondson WOC, Glen DM, Ives AR, Langdon CJ, Wiltshire CW (2002a) Dynamics of the relationship between a generalist predator and slugs over five years Ecology 83:137-147 doi:10.2307/2680127

Symondson WOC, Sunderland KD, Greenstone MH (2002b) Can generalist predators be effective biocontrol agents? Annu Rev Entomol 47:561-594 doi:10.1146/annurev.ento.47.091201.145240

Szigeti V, Körösi Á, Harnos A, Nagy J, Kis J (2016) Measuring floral resource availability for insect pollinators in temperate grasslands - a review Ecol Entomol 41:231-240 doi:10.1111/een.12298

Thies C, Roschewitz I, Tscharntke T (2005) The landscape context of cereal aphid-parasitoid interactions Proceedings of the Royal Society B-Biological Sciences 272:203-210 doi:10.1098/rspb.2004.2902

Thies C, Tscharntke T (1999) Landscape structure and biological control in agroecosystems Science 285:893-895 doi:10.1126/science.285.5429.893

Thomas CFG, Holland JM, Brown NJ (2002) The spatial distribution of carabid beetles in agricultural landscapes. In: Holland JM (ed) The agroecology of carabid beetles. Intercept Limited, Andover, Hampshire, UK,

Thomas CFG, Marshall EJP (1999) Arthropod abundance and diversity in differently vegetated margins of arable fields Agr Ecosyst Environ 72:131-144 doi:10.1016/s0167-8809(98)00169-8

Thompson PL, Davies TJ, Gonzalez A (2015) Ecosystem functions across trophic levels are linked to functional and phylogenetic diversity Plos One 10:19 doi:10.1371/journal.pone.0117595

Tilman D, Reich PB, Knops J, Wedin D, Mielke T, Lehman C (2001) Diversity and productivity in a long-term grassland experiment Science 294:843-845 doi:10.1126/science.1060391

Tixier P, Dagneaux D, Mollot G, Vinatier F, Duyck PF (2013) Weeds mediate the level of intraguild predation in arthropod food webs J Appl Entomol 137:702-710 doi:10.1111/jen.12060

Toft S, Wise DH (1999) Growth, development, and survival of a generalist predator fed single- and mixed-species diets of different quality Ecologia 119:191-197 doi:10.1007/s004420050776

Topping CJ (1993) Behavioural responses of three linyphiid spiders to pitfall traps Entomol Exp Appl 68:287-293

Topping CJ, Sunderland KD (1992) Limitations to the use of pitfall traps in ecological-studies exemplified by a study of species in a field of winter-wheat J Appl Ecol 29:485-491 doi:10.2307/2404516

Traugott M, Bell JR, Raso L, Sint D, Symondson WOC (2014) Generalist predators disrupt parasitoid aphid control by direct and coincidental intraguild predation Bull Entomol Res 102:239-247 doi: $10.1017 / \mathrm{s} 0007485311000551$

Trichard A, Alignier A, Biju-Duval L, Petit S (2013a) The relative effects of local management and landscape context on weed seed predation and carabid functional groups Basic and Applied Ecology 14:235-245 doi:10.1016/j.baae.2013.02.002

Trichard A, Alignier A, Chauvel B, Petit S (2013b) Identification of weed community traits response to conservation agriculture Agr Ecosyst Environ 179:179-186 doi:10.1016/j.agee.2013.08.012

Trichard A, Ricci B, Ducourtieux C, Petit S (2014) The spatio-temporal distribution of weed seed predation differs 
between conservation agriculture and conventional tillage Agr Ecosyst Environ 188:40-47 doi:10.1016/j.agee.2014.01.031

Tscharntke T et al. (2007) Conservation biological control and enemy diversity on a landscape scale Biol Control 43:294-309 doi:10.1016/j.biocontrol.2007.08.006

Tscharntke T et al. (2016) When natural habitat fails to enhance biological pest control - Five hypotheses Biol Conserv 204:449-458 doi:10.1016/j.biocon.2016.10.001

Tscharntke T, Rand TA, Bianchi FJJA (2005) The landscape context of trophic interactions: insect spillover across the crop-noncrop interface Ann Zool Fenn 42:421-432

Tscharntke T, Steffan-Dewenter I, Kruess A, Thies C (2002) Contribution of small habitat fragments to conservation of insect communities of grassland-cropland landscapes Ecological Applications 12:354-363 doi: $10.2307 / 3060947$

Tschumi M, Albrecht M, Bärtschi C, Collatz J, Entling MH, Jacot K (2016) Perennial, species-rich wildflower strips enhance pest control and crop yield Agr Ecosyst Environ 220:97-103 doi:http://dx.doi.org/10.1016/j.agee.2016.01.001

Tschumi M, Albrecht M, Entling MH, Jacot K (2015) High effectiveness of tailored flower strips in reducing pests and crop plant damage Proceedings of the Royal Society B-Biological Sciences 282:189-196 doi:10.1098/rspb.2015.1369

Tylianakis JM, Tscharntke T, Lewis OT (2007) Habitat modification alters the structure of tropical host-parasitoid food webs Nature 445:202-205 doi:10.1038/nature05429

Uyttenbroeck R et al. (2016) Pros and cons of flower strips for farmers. A review Biotechnologie, agronomie, société et environnement 20:1-9

Uyttenbroeck R, Hatt S, Piqueray J, Paul A, Bodson B, Francis F, Monty A (2015) Creating perennial flower strips: think functional! In: Cimpeanu SM, Fintineru G, Beciu S (eds) Conference Agriculture for Life, Life for Agriculture, vol 6. Agriculture and Agricultural Science Procedia. Elsevier Science Bv, Amsterdam, pp 95101. doi:10.1016/j.aaspro.2015.08.044

Uyttenbroeck R, Piqueray J, Hatt S, Mahy G, Monty A (2017) Increasing plant functional diversity is not the key for supporting pollinators in wildflower strips Agr Ecosyst Environ 249:144-155 doi:10.1016/j.agee.2017.08.014

Valantin-Morison M, Meynard J-M, Doré T (2007) Crop management and environment effects on insects in organic winter oil seed rape in France Crop Prot 26:1108-1120

Van Maanen R, Messelink GJ, Van Holstein-Saj R, Sabelis MW, Janssen A (2012) Prey temporarily escape from predation in the presence of a second prey species Ecol Entomol 37:529-535 doi:10.1111/j.13652311.2012.01395.x

van Rijn PCJ, Wäckers FL (2010) The suitability of field margin flowers as food sources for zoophagous hoverflies Landscape management for functional biodiversity 56:125-128

van Rijn PCJ, Wäckers FL (2016) Nectar accessibility determines fitness, flower choice and abundance of hoverflies that provide natural pest control J Appl Ecol:n/a-n/a doi:10.1111/1365-2664.12605

van Veen FJF, Brandon CE, Godfray HCJ (2009) A positive trait-mediated indirect effect involving the natural enemies of competing herbivores Oecologia 160:195-205 doi:10.1007/s00442-009-1288-y

van Veen FJF, Morris RJ, Godfray HCJ (2006) Apparent competition, quantitative food webs, and the structure of phytophagous insect communities. In: Annual Review of Entomology, vol 51. Annual Review of Entomology. pp 187-208. doi:10.1146/annurev.ento.51.110104.151120

Vanbergen AJ et al. (2010) Trophic level modulates carabid beetle responses to habitat and landscape structure: a pan-European study Ecol Entomol 35:226-235 doi:10.1111/j.1365-2311.2010.01175.x

Varennes YD, Boyer S, Wratten SD (2016) Nectar from oilseed rape and floral subsidies enhances longevity of an aphid parasitoid more than does host honeydew Biocontrol 61:631-638 doi:10.1007/s10526-016-9750-3

Vattala HD, Wratten SD, Phillips CB, Wäckers FL (2006) The influence of flower morphology and nectar quality on the longevity of a parasitoid biological control agent Biol Control 39:179-185 doi:10.1016/j.biocontrol.2006.06.003

Veddeler D, Tylianakis J, Tscharntke T, Klein AM (2010) Natural enemy diversity reduces temporal variability in wasp but not bee parasitism Oecologia 162:755-762 doi:10.1007/s00442-009-1491-x

Venjakob C, Klein AM, Ebeling A, Tscharntke T, Scherber C (2016) Plant diversity increases spatio-temporal niche complementarity in plant-pollinator interactions Ecology and Evolution 6:2249-2261 doi:10.1002/ece3.2026

Venturini EM, Drummond FA, Hoshide AK, Dibble AC, Stack LB (2017) Pollination reservoirs for wild bee habitat enhancement in cropping systems: a review Agroecology and Sustainable Food Systems 41:101-142 doi:10.1080/21683565.2016.1258377

Veres A, Petit S, Conord C, Lavigne C (2013) Does landscape composition affect pest abundance and their control by natural enemies? A review Agr Ecosyst Environ 166:110-117 doi:10.1016/j.agee.2011.05.027

Vialatte A, Plantegenest M, Simon JC, Dedryver CA (2007) Farm-scale assessment of movement patterns and 
colonization dynamics of the grain aphid in arable crops and hedgerows Agric For Entomol 9:337-346 doi:10.1111/j.1461-9563.2007.00347.x

Vialatte A et al. (2017) Landscape potential for pollen provisioning for beneficial insects favours biological control in crop fields Landsc Ecol 32:465-480 doi:10.1007/s10980-016-0481-8

Vickery J, Carter N, Fuller RJ (2002) The potential value of managed cereal field margins as foraging habitats for farmland birds in the UK Agr Ecosyst Environ 89:41-52 doi:10.1016/s0167-8809(01)00317-6

Violle C, Navas ML, Vile D, Kazakou E, Fortunel C, Hummel I, Garnier E (2007) Let the concept of trait be functional! Oikos 116:882-892

Violle C, Reich PB, Pacala SW, Enquist BJ, Kattge J (2014) The emergence and promise of functional biogeography Proceedings of the national academy of sciences 111:13690-13696 doi:10.1073/pnas.1415442111

Wäckers F, Bonifay C, Vet L, Lewis J (2006) Gustatory response and appetitive learning in Microplitis croceipes in relation to sugar type and concentration Anim Biol 56:193-203 doi:10.1163/157075606777304230

Wäckers FL (1999) Gustatory response by the hymenopteran parasitoid Cotesia glomerata to a range of nectar and honeydew sugars J Chem Ecol 25:2863-2877 doi:10.1023/a:1020868027970

Wäckers FL (2004) Assessing the suitability of flowering herbs as parasitoid food sources: flower attractiveness and nectar accessibility Biol Control 29:307-314 doi:10.1016/j.biocontrol.2003.08.005

Wäckers FL, Romeis J, van Rijn P (2007) Nectar and pollen feeding by insect herbivores and implications for multitrophic interactions. In: Annual Review of Entomology, vol 52. Annual Review of Entomology. Annual Reviews, Palo Alto, pp 301-323. doi:10.1146/annurev.ento.52.110405.091352

Wäckers FL, van Rijn PCJ (2012) Pick and mix: selecting flowering plants to meet the requirements of target biological control insects. In: Biodiversity and Insect Pests. John Wiley \& Sons, Ltd, pp 139-165. doi:10.1002/9781118231838.ch9

Wäckers FL, van Rijn PCJ, Bruin J (2005) Plant-provided food for carnivorous insects. Cambridge University Press, Cambridge, UK,

Wanner H, Gu HN, Gunther D, Hein S, Dorn S (2006) Tracing spatial distribution of parasitism in fields with flowering plant strips using stable isotope marking Biol Control 39:240-247 doi:10.1016/j.biocontrol.2006.06.001

War AR, Paulraj MG, Ahmad T, Buhroo AA, Hussain B, Ignacimuthu S, Sharma HC (2012) Mechanisms of plant defense against insect herbivores Plant signaling \& behavior 7:1306-1320 doi:10.4161/psb.21663

Warner DJ, Allen-Williams LJ, Ferguson AW, Williams IH (2000) Pest-predator spatial relationships in winter rape: implications for integrated crop management Pest Manage Sci 56:977-982 doi:10.1002/15264998(200011)56:11<977::aid-ps224>3.0.co;2-u

Webb CT, Hoeting JA, Ames GM, Pyne MI, Poff NL (2010) A structured and dynamic framework to advance traitsbased theory and prediction in ecology Ecology Letters 13:267-283 doi:10.1111/j.1461-0248.2010.01444.x

Weiss E, Stettmer C (1991) Unkräuter in der Agrarlandschaft locken blütenbesuchende Nutzinsekten an. vol Agrarökologie ; Bd. 1 Haupt, Bern,

Welch KD, Harwood JD (2014) Temporal dynamics of natural enemy-pest interactions in a changing environment Biol Control 75:18-27 doi:10.1016/j.biocontrol.2014.01.004

Wheater CP, Evans MEG (1989) The mandibular forces and pressures of some predacious coleoptera J Insect Physiol 35:815-820 doi:10.1016/0022-1910(89)90096-6

Wielgoss A, Tscharntke T, Rumede A, Fiala B, Seidel H, Shahabuddin S, Clough Y (2014) Interaction complexity matters: disentangling services and disservices of ant communities driving yield in tropical agroecosystems Proceedings of the Royal Society B-Biological Sciences 281 doi:10.1098/rspb.2013.2144

Wilby A, Anglin LA, Nesbit CM (2013) Plant species composition alters the sign and strength of an emergent multipredator effect by modifying predator foraging behaviour PLoS One 8:7 doi:10.1371/journal.pone.0070258

Wilby A, Orwin KH (2013) Herbivore species richness, composition and community structure mediate predator richness effects and top-down control of herbivore biomass Oecologia 172:1167-1177 doi:10.1007/s00442012-2573-8

Wilby A, Thomas MB (2002a) Are the ecological concepts of assembly and function of biodiversity useful frameworks for understanding natural pest control? Agric For Entomol 4:237-243 doi:10.1046/j.14619563.2002.00165.x

Wilby A, Thomas MB (2002b) Natural enemy diversity and pest control: patterns of pest emergence with agricultural intensification Ecology Letters 5:353-360 doi:10.1046/j.1461-0248.2002.00331.x

Wilby A, Villareal SC, Lan LP, Heong KL, Thomas MB (2005) Functional benefits of predator species diversity depend on prey identity Ecol Entomol 30:497-501 doi:10.1111/j.0307-6946.2005.00717.x

Williams IH (2006) Integrating parasitoids into management of pollen beetle onoilseed rape Agron Res 4:465-470

Winder L, Alexander CJ, Holland JM, Symondson WOC, Perry JN, Woolley C (2005) Predatory activity and spatial pattern: the response of generalist carabids to their aphid prey J Anim Ecol 74:443-454 doi:10.1111/j.13652656.2005.00939.x

Winkler K, Wackers FL, Kaufman LV, Larraz V, van Lenteren JC (2009) Nectar exploitation by herbivores and their 
parasitoids is a function of flower species and relative humidity Biol Control 50:299-306 doi:10.1016/j.biocontrol.2009.04.009

Winkler K, Wackers FL, Termorshuizen AJ, van Lenteren JC (2010) Assessing risks and benefits of floral supplements in conservation biological control Biocontrol 55:719-727 doi:10.1007/s10526-010-9296-8

Winqvist $C$ et al. (2014) Species' traits influence ground beetle responses to farm and landscape level agricultural intensification in Europe J Insect Conserv 18:837-846 doi:10.1007/s10841-014-9690-0

Wood SA, Karp DS, DeClerck F, Kremen C, Naeem S, Palm CA (2015) Functional traits in agriculture: agrobiodiversity and ecosystem services Trends in Ecology \& Evolution 30:531-539 doi:10.1016/j.tree.2015.06.013

Wood TJ, Holland JM, Goulson D (2017) Providing foraging resources for solitary bees on farmland: current schemes for pollinators benefit a limited suite of species J Appl Ecol 54:323-333 doi:10.1111/13652664.12718

Woodcock BA et al. (2009) Responses of invertebrate trophic level, feeding guild and body size to the management of improved grassland field margins J Appl Ecol 46:920-929 doi:10.1111/j.1365-2664.2009.01675.x

Woodcock BA, Potts SG, Westbury DB, Ramsay AJ, Lambert M, Harris SJ, Brown VK (2007) The importance of sward architectural complexity in structuring predatory and phytophagous invertebrate assemblages Ecol Entomol 32:302-311 doi:10.1111/j.1365-2311.2007.00869.x

Woodcock BA et al. (2010) Impact of habitat type and landscape structure on biomass, species richness and functional diversity of ground beetles Agr Ecosyst Environ 139:181-186 doi:10.1016/j.agee.2010.07.018

Woodcock BA, Westbury DB, Potts SG, Harris SJ, Brown VK (2005) Establishing field margins to promote beetle conservation in arable farms Agr Ecosyst Environ 107:255-266 doi:10.1016/j.agee.2004.10.029

Woodcock BA et al. (2008) Effects of seed mixture and management on beetle assemblages of arable field margins Agr Ecosyst Environ 125:246-254 doi:10.1016/j.agee.2008.01.004

Wratten SD, Gillespie M, Decourtye A, Mader E, Desneux N (2012) Pollinator habitat enhancement: benefits to other ecosystem services Agr Ecosyst Environ 159:112-122 doi:10.1016/j.agee.2012.06.020

Yoo HJS, O'Neil RJ (2009) Temporal relationships between the generalist predator, Orius insidiosus, and its two major prey in soybean Biol Control 48:168-180 doi:10.1016/j.biocontrol.2008.10.007

Zaller J, Moser D, Drapela T, Frank T (2009a) Ground-dwelling predators can affect within-field pest insect emergence in winter oilseed rape fields Biocontrol 54:247-253 doi:10.1007/s10526-008-9167-8

Zaller JG, Moser D, Drapela T, Schmöger C, Frank T (2008) Effect of within-field and landscape factors on insect damage in winter oilseed rape Agr Ecosyst Environ 123:233-238 doi:10.1016/j.agee.2007.07.002

Zaller JG, Moser D, Drapela T, Schmöger C, Frank T (2009b) Parasitism of stem weevils and pollen beetles in winter oilseed rape is differentially affected by crop management and landscape characteristics Biocontrol 54:505-514 doi:10.1007/s10526-009-9212-2

Zhao ZH, Hui C, He DH, Li BL (2015) Effects of agricultural intensification on ability of natural enemies to control aphids Scientific Reports 5:7 doi:10.1038/srep08024 